\title{
PRENSA Y ELECCIONES GENERALES EN EUSKADI (12 DE MARZO DE 2000) O LAS ELECCIONES AL «ZOCO MORUNO» ${ }^{1}$
}

\author{
Ignacio María Beobide Ezpeleta
}

\section{INTRODUCCIÓN GENERAL}

Este trabajo analiza ${ }^{2}$ desde el punto de vista ideológico las campañas del Partido Nacionalista Vasco y de Eusko Alkartasuna, únicos partidos nacionalistas vascos, que se presentaron a las Elecciones Genera-

${ }^{1}$ Palabras despectivas, que el presidente del PNV utilizó para referirse a Madrid (El Correo, 1-3-00 (19)), tal vez, recordando aquellas otras que el canónigo Antonio Pildaín pronunció el 12 de julio de 1931 en Gernika con ocasión de la despedida de los diputados pro Estatuto de Estella: «Vamos a reivindicar nuestra libertad religiosa porque no estamos dispuestos a entregar nuestro culto en manos de esas hordas que incendian bárbaramente, más que africanamente, porque en esta ocasión, el Africa empieza en Madrid» (AGIRRE Y LEKUBE, José Antonio: Entre la libertad y la revolución 1930-1935. La verdad de un lustro en el País Vasco; E. Verdes Achirica, Bilbao, p. 105).

2 Este análisis se hace utilizando la prensa como fuente de información. Son cinco los periódicos consultados: El Correo, Deia, El País, El Mundo y Gara. La utilización de la edición para Vizcaya condiciona algunos de los datos, principalmente, los relativos a las intervenciones de los políticos.

La cuantificación de las campañas se basa en las aportaciones de El Correo por su información más constante, uniforme y homogénea. Por otra parte, EA no disponía de un periódico de las características de Deia. Aun así, El Correo da una información bastante más amplia sobre el PNV que sobre EA, probablemente, porque así lo fueron sus campañas y, también, porque la trascencendencia política del PNV (y de sus lectores) era mayor que la de EA.

La estructura, metodología, unidades informativas, anotaciones y formas de citas utilizadas no varían en nada substancial con respecto a las utilizadas en mis trabajos anteriores sobre elecciones en el País Vasco, que pretenden ser partes de un trabajo general sobre los procesos electorales vascos desde 1977 (ver Revista Estudios de Deusto, vol. 46/2, «Elecciones al Parlamento Vasco de 25 de octubre de 1998», pp. 11-89, y otros trabajos allí citados). 
les del 12 de marzo de 2000 y obtuvieron escaños. El estudio, como en otros trabajos anteriores, pretende destacar la justificación de la petición del voto que hicieron ambas formaciones políticas. Eran desde 1977 las octavas Elecciones Generales y sus resultados dieron al Partido Popular la mayoría absoluta de los escaños tanto en el Congreso de los Diputados como en el Senado.

Del mapa electoral cabe destacar los siguientes datos:

\section{Total Congreso}

\begin{tabular}{lrlrrr}
\hline \multicolumn{1}{c}{ Distribución del escrutinio } & Resultados & \multicolumn{1}{c}{ Votos } & $\%$ & Escaños \\
\hline \multirow{2}{*}{ Censo } & 33.969 .640 & Partido Popular & 10.321 .178 & 44,52 & 183 \\
Votantes & 23.339 .490 & PSOE - progresistas & 7.918 .752 & 34,16 & 125 \\
Votos a candidatura & 22.814 .467 & Convergencia i Unió & 970.421 & 4,19 & 15 \\
Votos en blanco & 366.823 & Izquierda Unida & 1.263 .043 & 5,45 & 8 \\
Votos nulos & 158.200 & Partido Nacionalista Vasco & 353.953 & 1,53 & 7 \\
Diputados a elegir & 350 & Coalición Canaria & 248.261 & 1,07 & 4 \\
Participación(\%) & 68,71 & Bloque Nacionalista Galego & 306.268 & 1,32 & 3 \\
Abstención (\%) & 31,29 & Partido Andalucista & 206.255 & 0,89 & 1 \\
& & Esquerra Republicana & & & \\
& & de Catalunya & 194.715 & 0,84 & 1 \\
& & Iniciativa per Catalunya-Vds. & 119.290 & 0,51 & 1 \\
& & Eusko Alkartasuna & 100.742 & 0,43 & 1 \\
& Chunta Aragonesista & 75.356 & 0,33 & 1 \\
\hline
\end{tabular}

Total Senado

\begin{tabular}{lrlr}
\hline \multicolumn{2}{c}{ Distribución del escrutinio } & Resultados & Escaños \\
\hline Censo & 33.969 .640 & Partido Popular & 127 \\
Votantes & 23.382 .667 & PSOE - progresistas & 61 \\
Votos a candidatura & 22.156 .793 & Convergencia i Unió & 8 \\
Votos en blanco & 642.682 & Partido Nacionalista Vasco & 6 \\
Votos nulos & 583.192 & Coalición Canaria & 5 \\
Senadores a elegir & 208 & PIL & 1 \\
Participación $(\%)$ & 68,83 & & \\
Abstención $(\%)$ & 31,17 & & \\
\hline
\end{tabular}


Parcial Congreso (Comunidad Autónoma del País Vasco)

\begin{tabular}{lrlrrr}
\hline \multicolumn{1}{c}{ Distribución del escrutinio } & Resultados & Votos & $\%$ & Escaños \\
\hline Censo & 1.810 .666 & Partido Nacionalista Vasco & 347.417 & 30,38 & 7 \\
Votantes & 1.155 .999 & Partido Popular & 323.235 & 28,26 & 7 \\
Votos a candidatura & 1.109 .319 & PSE-EE & 266.583 & 23,31 & 4 \\
Votos en blanco & 34.381 & Eusko Alkartasuna & 86.557 & 7,57 & 1 \\
Votos nulos & 12.299 & Izquierda Unida & 62.293 & 5,45 & 0 \\
Diputados a elegir & 19 & Los Verdes & 10.121 & 0,88 & 0 \\
Participación (\%) & 63,84 & Partido Humanista & 3.058 & 0,27 & 0 \\
Abstención (\%) & 36,16 & Partido del Karma democrático & 2.759 & 0,24 & 0 \\
& & Partido de la Ley Natural & 2.378 & 0,21 & 0 \\
& & P. Obrero Socialista Int. & 3.621 & 0,32 & 0 \\
\hline
\end{tabular}

\section{Parcial Senado (Comunidad Autónoma del País Vasco)}

\begin{tabular}{lrlc}
\hline \multicolumn{1}{c}{ Distribución del escrutinio } & Resultados & Escaños \\
\hline Censo & 1.810 .666 & Partido Nacionalista Vasco & 6 \\
Votantes & 1.164 .717 & Partido Popular & 5 \\
Votos a candidaturas & 1.074 .081 & PSE-EE & $1^{3}$ \\
Votos en blanco & 46.770 & & \\
Votos nulos & 43.866 & & \\
Senadores a elegir & 12 & & \\
Participación (\%) & 64,33 & & \\
Abstención (\%) & 35,67 & & \\
\hline
\end{tabular}

3 Ver «Elecciones a Cortes Generales 2000», Colección Documentos Electorales 9; Ministerio del Interior, pp. 3, 6, 9, 357, 358, 359, 362, 367, 368 y 372. Los resultados electorales de la Comunidad Autónoma del País Vasco (no los totales al Congreso y al Senado) se pueden consultar, también, en «Elecciones Generales 2000»; Gobierno Vasco, Departamento de Interior, Dirección de Procesos Electorales y Documentación. Los resultados electorales por Territorios Históricos en las mismas fuentes son los siguientes:

Parcial Congreso (Alava)

\begin{tabular}{lrlrrr}
\hline \multicolumn{2}{c}{ Distribución del escrutinio } & Resultados & Votos & $\%$ & Escaños \\
\hline Censo & 244.477 & Partido Popular & 66.267 & 39,10 & 2 \\
Votantes & 171.808 & PSE-EE & 41.182 & 24,30 & 1 \\
Votos a candidatura & 164.325 & Partido Nacionalista Vasco & 35.155 & 20,74 & 1 \\
Votos en blanco & 5.163 & & & & \\
Votos nulos & 2.320 & & & & \\
Diputados a elegir & 4 & & & & \\
Participación (\%) & 70,28 & & & & \\
Abstención (\%) & 29,72 & & & & \\
\hline
\end{tabular}


La agregación de los votos y escaños obtenidos por los partidos en Elecciones Generales en el País Vasco según criterios de nacionalismo versus no nacionalismo, que únicamente tiene en cuenta los votos de

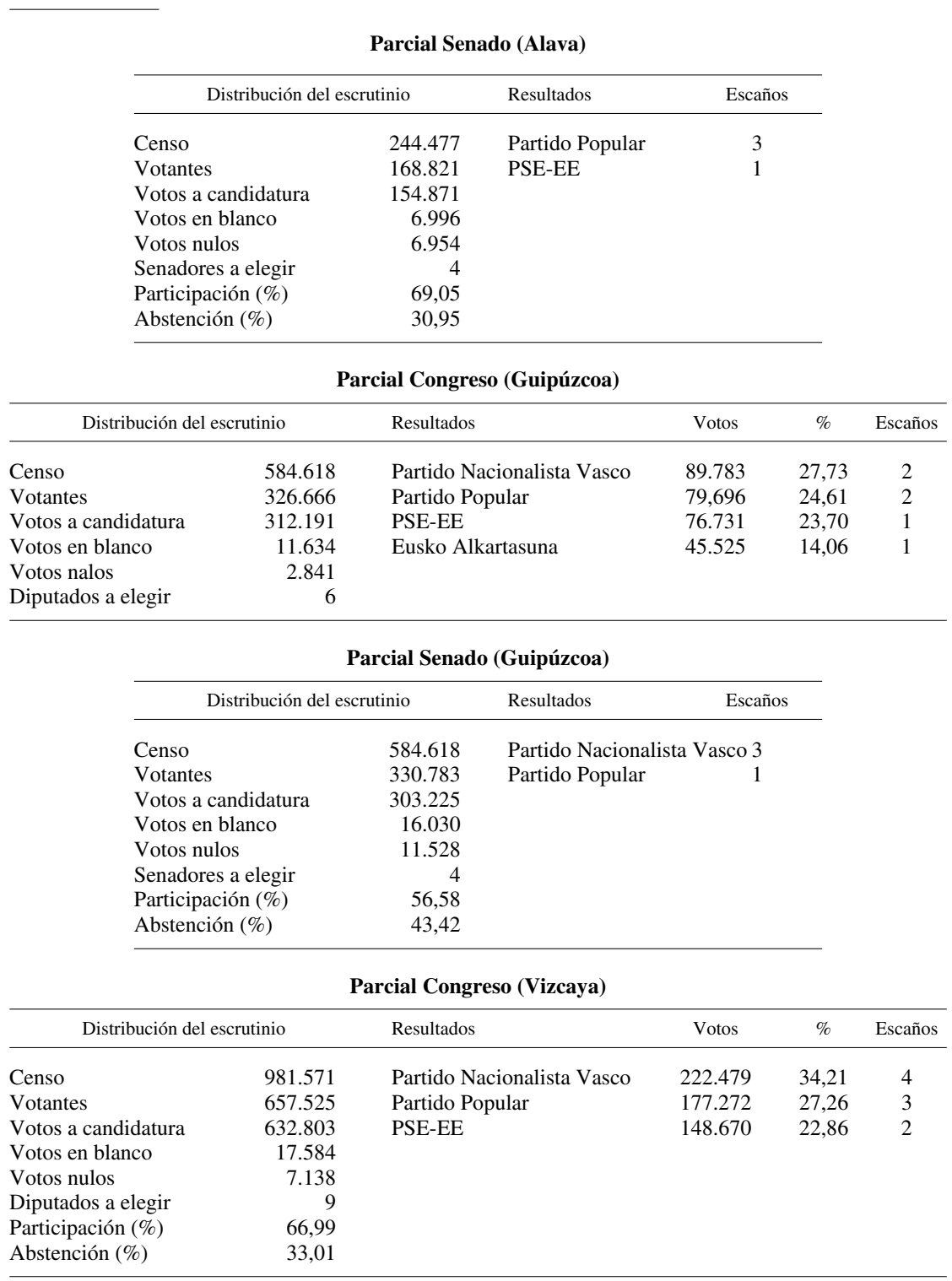


los partidos que sacaron algún escaño al Congreso, nos da esta evolución desde las primeras elecciones generales de 1977:

\begin{tabular}{lllllll}
\hline Año & Nacionalismo & & No nacionalismo & & $\begin{array}{c}\text { Abstención } \\
(\%)\end{array}$ \\
\hline 1977 & PNV+EE & 357.610 & $(9)$ & PSE+UCD+AP & $442.358(12)$ & 23,07 \\
1979 & PNV+HB+EE & $505.075(11)$ & PSE+UCD & $358.842(10)$ & 34,03 \\
1982 & PNV+HB+EE & $647.077(11)$ & PSE+AP.UCD. & $487.768(10)$ & 20,63 \\
1986 & PNV+HB+EE & $597.807(12)$ & PSE+AP.PDP. & $402.885(9)$ & 32,42 \\
1989 & PNV+HB+EE+EA & $659.667(13)$ & PSE+PP & $337.347(8)$ & 33,11 \\
1993 & PNV+HB+EA.EUE & 580.419 & $(8)$ & PSE.EE+PP & $469.200(11)$ & 30.27 \\
1996 & PNV+HB+EA & 574.274 & $(8)$ & PSE.EE+PP+IU & $645.918(11)$ & 28,47 \\
2000 & PNV+EA & 433.974 & $(8)$ & PP+PSE.EE & $589.818(11)$ & $36,16^{4}$ \\
\hline
\end{tabular}

La campaña de los nacionalistas tuvo un eje central, en torno al que giraron las demás cuestiones básicas planteadas. Este eje central lo constituyó el Pacto de Estella (o Pacto de Lizarra) y, más en concreto, su fracaso. Es cierto que en cualquier tipo de elecciones, desde las generales hasta las municipales, la variable nacionalista introduce novedades argumentales, pero en este caso, directa o indirectamente, el pacto nacionalista de Estella polarizó o focalizó el enfrentamiento electoral y no, precisamente, el debate electoral. La misma prensa recoge dos campañas, la general y la específica de Euskadi. En ambas está presente la problemática planteada por los partidos nacionalistas, pero la diferencia es cualitativa.

\begin{tabular}{lrrr} 
& & & \\
& & \\
& & & \\
\multicolumn{2}{c}{ Distribución del escrutinio } & Resultados & Escaños \\
\hline Censo & 981.571 & Partido Nacionalista Vasco 3 \\
Votantes & 665.113 & Partido Popular & 1 \\
Votos a candidatura & 615.985 & & \\
Votos en blanco & 23.744 & & \\
Votos nulos & 25.384 & & \\
Senadores a elegir & 4 & & \\
Participación (\%) & 67,76 & & \\
Abstención (\%) & 32,24 & & \\
\end{tabular}

4 Ver Gobierno Vasco, Departamento de Interior, «Elecciones Generales 1977-2000», resultados Comunidad Autónoma del País Vasco y elaboración propia. El País, 8-3-00 (5), da otra versión, que no especifica los criterios seguidos y distorsiona los resultados. Los números entre paréntesis son los escaños obtenidos. 
El fracaso del Pacto de Estella aglutina, en primer lugar, tanto la condena de la ruptura de ETA y sus asesinatos, especialmente los asesinatos de Fernando Buesa y Jorge Díez perpetrados inmediatamente antes de comenzar la campaña, como el reconocimiento de la validez de los principios inspiradores del Pacto. El mensaje es claro. El acuerdo era y es valioso. Era ETA quien no había cumplido los pactos y había abandonado el entendimiento entre nacionalistas. Las consecuencias negativas iban contra el nacionalismo. Pero ETA podía volver a una nueva tregua o, al menos, su brazo político podía independizarse de aquélla. Buena parte del espacio de la campaña nacionalista lo ocupó esta cuestión. ETA y Euskal Herritarrok (EH) harían con sus comunicados e intervenciones interpretaciones radicalmente distintas.

El fracaso de Estella se manifiesta, en segundo lugar, en la campaña abstencionista de EH y en la retirada de sus candidaturas. El nacionalismo participante verá en esta actitud un grave perjuicio para los intereses de Euskadi, ya por perder representación, ya por potenciar a los enemigos del pueblo vasco. La interpretación de EH descubrirá otras dimensiones del problema, las disensiones internas de los firmantes de Estella.

EH dedicó su especial campaña a dos temas: la justificación de su abstención, por un lado, y, por otro, la crítica y denuncia de sus anteriores socios, amén de la reivindicación de los espacios gratuitos en los medios de comunicación, que aquí no interesa.

La abstención, se dijo, no era una imposición de ETA, sino una decisión autónoma, debatida en los comités locales y ratificada por la Asamblea Nacional ${ }^{5}$. La abstención era, además, la mejor inversión para la paz y para la democracia vasca ${ }^{6}$, ya que se trataba de comicios «transgénicos», propios de una democracia «no natural», impuestos «artificialmente» por los sistemas políticos francés y español. Los vascos necesitaban «una democracia natural, la democracia vasca e instituciones nacionales vascas» ${ }^{7}$. Las elecciones eran una «injerencia» en la construcción nacional vasca ${ }^{8}$ y, según esto, lo más consecuente era la abstención ${ }^{9}$.

Por todo ello, EH pidió la abstención no sólo a sus simpatizantes y votantes, sino, también, a los votantes de todos los firmantes del Pacto de Lizarra ${ }^{10}$.

5 Ver El Correo, 26-2-00 (26).

6 Ver El Correo, 27-2-00 (40).

7 El Correo, 29-2-00 (17), palabras de Otegi.

8 Ver El Correo, 8-3-00 (20).

9 Ver El Correo, 6-3-00 (18).

10 Ver El Correo, 5-3-00 (26), Otegi, y El Correo, 6-3-00 (18), Karmelo Landa. 
El segundo de los temas, la crítica y denuncia del PNV y EA, fue la parte más relevante de sus intervenciones, que, como en el caso del Partido Popular, prestaron más atención al primero que al segundo. Su participación fue calificada como propia de buitres en busca de los votos de Euskal Herritarrok ${ }^{11}$. Con ello demostraban su cobardía y falta de determinación para realizar la construcción nacional ${ }^{12}$.

Votar al PNV significaba «premiar su falta de coraje» ${ }^{13}$ y aceptar sus terceras vías, en las que era «maestro», que no eran otra cosa que espacios de «larga confrontación» ${ }^{14}$. El PNV debía elegir entre gestionar el «marco de imposición y antidemocrático con las fuerzas estatales o venir con la izquierda abertzale para ejercer un marco de soberanía para nuestro país» ${ }^{15}$. Con su irresponsable participación hacía «el caldo gordo al próximo Gobierno del Partido Popular» ${ }^{16}$ e Ibarretxe realizaba la «ignominia de presidir una comunidad autónoma española» ${ }^{17}$. La participación electoral nacionalista, tanto del PNV como de EA, suponía aceptar la ciudadanía española ${ }^{18}$.

Al final de la campaña Euskal Herritarrok recordó su interpretación del Pacto de Estella, que ya había defendido en las Elecciones autonómicas de $1998^{19}$, mediante la cual denunció la traición y la deslealtad del resto de nacionalistas a lo acordado y subió la agresividad de sus críticas al PNV y EA. La irrupción del comunicado de ETA en la campaña, al que posteriormente se refiere este trabajo, desvela que la explicación de la misma está en el fracaso del Pacto de Estella.

Otegi calificó de «deslealtad» y «mentira» la interpretación de que la ayuda de EH al lehendakari Ibarretxe en su investidura y Gobierno significara su «aterrizaje institucional». La coalición respaldó a Ibarretxe «no para profundizar ni dar estabilidad» al vigente sistema político, sino para trabajar desde el Gobierno autonómico en «construir» uno nuevo. Esta versión la confirmaba Otegi interpretando que, en su comunicado, ETA volvía a insistir en lo mismo. ETA «vuelve a plantear — dice Otegi- que la oportunidad histórica que se abrió no se quiebra

11 Ver El Correo, 29-2-00 (17) y 2-3-00 (20).

12 Ver El Correo, 2-3-00 (20).

13 El Correo, 3-3-00 (15), palabras de Kepa Gordejuela.

14 El Correo, 4-3-00 (24).

15 El Correo, 5-3-00 (26), palabras de Otegi. Ver, asimismo, El Correo, 7-3-00 (23).

${ }_{16}$ El Correo, 6-3-00 (18). Ver, asimismo, El Correo, 5-3-00 (26).

17 El Correo, 5-3-00 (26).

18 Ver El Correo, 8-3-00 (20).

19 Ver mi trabajo «Elecciones al Parlamento Vasco de 25 de octubre de 1998», Revista Estudios de Deusto, vol. 46/2, julio-diciembre 1998, pp. 11-89, donde aparecen las dos versiones del Pacto de Estella. 
ni hay un cambio de estrategia.(...) vuelve a emplazarnos a todos a que seamos capaces de articular una dinámica, con determinación, que permita acceder a otro escenario de democracia y paz» ${ }^{20}$. Según Otegi, PNV y EA conocían cuáles eran los compromisos que posibilitaron la tregua de ETA y sabían con exactitud en el momento de las elecciones los pasos que había que dar para «hacer reflexionar a ETA». No había más fórmula que «profundizar en la alianza entre abertzales para definir el proceso» ${ }^{21}$.

Otegi culminó sus ataques a los nacionalistas al afirmar que el lehendakari Ibarretxe, al romper el pacto con Euskal Herritarrok, había reforzado las tesis de Jaime Mayor Oreja, porque «si EH es ETA, ha estado gobernando con ETA, y si no lo es, ¿por qué ha roto los pac$\operatorname{tos} ? \gg^{22}$.

El fracaso de Estella se manifiesta, en tercer lugar, en el miedo al avance de populares y socialistas, como resultado de la desunión abertzale, del desprestigio nacionalista y, previamente, del significado del Pacto. Aunque en determinados momentos de la campaña, especialmente al principio, los dos grupos son tratados como integrantes de un supuesto bloque antinacionalista, el desarrollo de la campaña definirá al Partido Popular como el principal enemigo del nacionalismo y el mayor beneficiario de la división nacionalista. El amplio espacio, que el PP ocupó en las campañas nacionalistas, pretendía destacar las nefastas consecuencias derivadas de la desunión nacionalista.

El Partido Popular, por su parte, hizo de la presencia de ETA y EH en el pacto y de sus manifiestas interpretaciones el centro de su campaña electoral para el País Vasco. Destaca en esta campaña, en primer lugar, la definición del problema vasco. No se trataba tanto de un problema de fractura social, cuanto de un problema de falta de libertad. No era «una cuestión de autogobierno insatisfecho, sino la voluntad de implantar, por la violencia terrorista, un régimen de nacionalismo étnico en Europa» ${ }^{23}$. El voto, así, al PNV significaba votar al Pacto de Estella, a la independencia y al radicalismo e ir en contra de la Constitución y el Estatuto ${ }^{24}$. Estella era el resultado de un pacto secreto entre ETA y el $\mathrm{PNV}^{25}$, de manera que resultaba al PNV más cómodo censurar al PP

\footnotetext{
20 El Correo, 9-3-00 (30).

21 El Correo, 10-3-00 (27).

22 El Correo, 10-3-09 (27).

23 El Correo 29-2-00 (14), declaraciones de Aznar al diario Le Monde. Ver, asimismo, El Correo, 1-3-00 (12).

24 Ver El Correo, 26-2-00 (26).

25 Ver El Correo, 7-3-00 (21).
} 
que a los terroristas y menos preocupante el fin del terrorismo que el espíritu de Ermua ${ }^{26}$. La radicalización del PNV, hasta el punto de asumir las tesis de ETA, quería evitar el intento de la banda y EH de «sustituir políticamente al $\mathrm{PNV} \gg^{27}$.

En segundo lugar, derrotar al PNV para que saliera del pacto de Estella y cambiara su estrategia era prioritario para el Partido Popular. La normalidad democrática llegaría con la renuncia del PNV al pacto con ETA, «sustanciado» por la permanencia del Pacto de Estella. El Partido Popular pedía el voto para ejecutar políticas claras, serias y contundentes contra la violencia de ETA, para frenar al nacionalismo y, sobre todo, para emerger como una alternativa real de Gobierno en Euskadi. Esto requería «superar el miedo físico a ETA y el miedo reverencial al $\mathrm{PNV}$ », es decir, «menos complejos» ${ }^{28}$. Se trataba de decir en las urnas, según Mayor Oreja, «basta ya» a ETA, al Pacto de Estella y a tantas mentiras dichas por los abertzales ${ }^{29}$. Las urnas debían destacar el fracaso del nacionalismo, que en su huida hacia adelante llevaba a la división social, y que los «gritos y radicalismo» de Arzalluz, no obstante su discurso contradictorio, trataban de ocultar ${ }^{30}$.

No habría, por último, según el mensaje popular, ningún pacto postelectoral con el PNV, si éste no cambiaba, ni habría tampoco ningún foro de diálogo, si ETA y EH no dejaban las armas ${ }^{31}$.

El análisis de las campañas de los partidos nacionalistas PNV y EA revela que cada uno de ellos hizo, en realidad, dos campañas. Una fue dirigida a mostrar el proyecto político o imagen política en contraposición con los partidos participantes, principalmente el Partido Popular y, en menor grado, el Partido Socialista. Este planteamiento disputaba el voto inmediato y real, y lo hacía desde la variable (en la óptica nacionalista) de nacionalismo vasco versus antinacionalismo vasco, aunque por imperativos de un nacionalismo social que se había demostrado más débil de lo que se pensó por parte de los firmantes del Pacto de Estella, se atemperaron mucho los contenidos estrictamente nacionalistas. La otra campaña fue dirigida a los no participantes en

26 Ver El Correo, 1-3-00 (20) y 28-2-00 (14).

27 El Correo, 4-3-00 (24).

${ }^{28}$ El Correo, 27-2-00 (40), palabras de Jaime Mayor Oreja. Ver, sobre estas cuestiones: El Correo, 25-2-00 (25); 26-2-00 (26); 2-3-00 (18); 5-3-00 (23); 11-3-00 (21).

29 El Correo, 4-3-00 (24).

${ }^{30}$ El Correo, 3-3-00 (21). Ver, también, El Correo, 4-3-00 (24); 7-3-00 (21); 11-3-00 (21).

31 Ver El Correo, 27-2-00 (40); 29-2-00 (14); 3-3-00 (21); 5-3-00 (23); 7-3-00 (21); 8-3-00 (15). 
las elecciones, pero que habían sido socios de Estella, Euskal Herritarrok y ETA. Aquí la variable utilizada fue el cumplimiento y la fidelidad al pacto versus engaño y deslealtad al mismo. Lo que se disputaba no era el voto inmediato, sino la legitimidad nacionalista y el liderazgo dentro de un nacionalismo unido. Pero ambas campañas eran interdependientes, no sólo porque también se buscaban votos perdidos de EH, sino, principalmente, porque el auge del antinacionalismo se producía, según la interpretación nacionalista, por la división nacionalista.

Esta campaña interna al nacionalismo, que incluyó alguna que otra crítica entre PNV y EA, más bien mostraba un problema sin solución. Todos parecían estar deseando recuperar la unidad nacionalista. Así mismo, parecía existir la convicción general de que tal unidad era imprescindible para el éxito futuro del nacionalismo o, por lo menos, para evitar su retroceso. Sin embargo, la campaña reflejaba la imposibilidad de tal unidad no sólo por la incompatibilidad de posturas en torno a la violencia, objetivos (a pesar de la necia afirmación de unidad en los objetivos y separación en los métodos), actitud institucional, ruptura política e intereses en juego, sino, porque cualquier renuncia a las propias posiciones en estas cuestiones marginaría al que lo hiciese de toda posibilidad de liderazgo nacionalista. El fracaso del Pacto de Estella era la prueba. No obstante, el nacionalismo pragmático, especialmente el del PNV, no parecía excluir la unidad, al menos circunstancial, con $\mathrm{EH}$, si ésta mostraba alguna independencia con respecto a una ETA activa.

\section{LA CAMPAÑA DEL PARTIDO NACIONALISTA VASCO}

\section{Datos básicos}

Fue más extensa esta campaña que la celebrada cuatro años antes para las Elecciones Generales del 3 de marzo de 1996 y, asimismo, que la de las Elecciones Autonómicas de 25 de octubre de 1998. El total de unidades informativas fue de 1.959 , de las cuales 1.781 correspondieron al trabajo de los propagandistas del PNV y el resto fue aportación de la prensa al ofrecer al lector resúmenes del programa electoral.

Las 1.781 unidades informativas se repartieron entre la imagen del partido o proyecto político $(29,75 \%)$ y la crítica a los partidos políticos $(70,24 \%)$, constituyendo esta distribución una de las mayores distancias entre ambos aspectos de una campaña electoral celebrada en el 
País Vasco ${ }^{32}$. Predominó, según esto, la crítica al adversario político, es decir, la campaña negativa, sobre la exposición del propio proyecto político.

Los temas políticos nacionalistas, stricto sensu, pasaron casi desapercibidos. Sólo ocuparon el 7,35\% del proyecto político o imagen, es decir, el 2,18\% del total de la campaña. Por el contrario, tuvo importancia la estrategia nacionalista por la paz (política antiterrorista), que ocupó el 78,67\% de la imagen y el 23,41\% de la campaña. Breves referencias a la democracia e inocencia moral o política del partido y a las selecciones vascas cerraron este apartado de los temas no nacionalistas de la campaña. Las alusiones al gobierno postelectoral sólo alcanzaron el 3,39\%, es decir, el 1,01\% del total.

En cuanto a los partidos políticos, fue el Partido Popular el que acaparó la crítica más amplia de los nacionalistas con un 59,87\% de este apartado, lo que supuso un $42,05 \%$ del total de la campaña ${ }^{33}$. Según esto, el Partido Popular no estuvo lejos de ocupar la mitad de la campaña nacionalista. El segundo foco de crítica se centró en Euskal Herritarrok, a pesar de que no se presentaba a las elecciones. Un $28,61 \%$ de esta parte, el 20,10\% de la campaña, fue dirigido contra $\mathrm{EH}$. El tercer lugar fue para el Partido Socialista de Euskadi con un 8,23\% (5,78\% de la campaña) ${ }^{34}$. Eusko Alkartasuna pasó casi desapercibida con el $3,27 \%(2,30 \%)$. Alguna denuncia de los medios de comunicación culminó esta parte.

En la campaña intervinieron Arzalluz, Anasagasti, Egibar, Ibarretxe, Imaz, Josu Erkoreka, Ochoa de Erice, Azkuna, Margarita Uría, González de Txabarri y Urbiola. Unicamente la participación de los cinco primeros tuvo relevancia. Destacó la de Arzalluz con el 35,55\% de las intervenciones, que alcanzaron casi la tercera parte de cuanto se dijo $(32,58 \%)$. Le siguieron Anasagasti con el $20 \%$ de intervenciones y

32 En las Elecciones Generales de 1996, la distancia estuvo entre el 46,18\% (imagen, identidad o proyecto político) y 53,82\% (crítica electoral o crítica a los partidos políticos). En las Elecciones Autonómicas de 1998, entre el 50,62\% y el 49,34\%. Ver estos datos, respectivamente, en Estudios de Deusto, vol. 44/1, enero-junio 1996, en mi trabajo «Elecciones Generales del 96. La argumentación nacionalista en el País Vasco», p. 60; asimismo, en Estudios de Deusto, vol. 46/2, julio-diciembre 1998, en mi trabajo «Elecciones al Parlamento Vasco de 25 de octubre de 1998», p. 15.

33 En las Elecciones Generales de 1996, el Partido Popular acaparó el 62,31\% de la crítica y el 33,54\% del total de la campaña (Estudios de Deusto, vol. 44/1, o.c. pp. 61 y 79); en las Elecciones Autonómicas de 1998, el $42 \%$ de la crítica y el 20,72\% de la campaña (Estudios de Deusto, vol. 46/2, julio-diciembre 1998, p. 15.)

${ }^{34}$ Ibídem, datos de anteriores elecciones: $11,06 \%$ y 5,95\%, (Elecciones Generales, 1996) y $45 \%$ y $22,4 \%$ (Elecciones Autonómicas, 1998). 
el $25,54 \%$ de extensión; Egibar con el $11,11 \%$ y el $15,29 \%$, respectivamente; Ibarretxe con el $15,55 \%$ y el $12,43 \%$, e Imaz con el $4,44 \%$ y $7,28 \%$. La participación de los demás mencionados tanto en ocasiones como en amplitud de las mismas fue mínima.

\section{El desarrollo de la campaña}

\section{A) La imagen del partido o proyecto político}

1. El contenido nacionalista

Los datos del sondeo publicado por El Correo $^{35}$ decían que en un supuesto referéndum sobre la independencia del País Vasco el 31,6\% de los encuestados votarían a favor, mientras que el 43,1\% lo haría en contra, siendo la abstención del 16,6\%. El número de votantes del Partido Nacionalista a favor de la independencia, según la misma encuesta, era del $36 \%$.

Con estos datos concordaba la poca atención que la propaganda del PNV dedicó a los temas estrictamente nacionalistas, incluyendo entre ellos, como se ha hecho en otros trabajos, cuestiones como la autonomía, que no son en sí mismas nacionalistas y, menos aún, en un momento en el que se planteó la superación del Estatuto. Aún así, apenas rebasó el 2\% el recurso al nacionalismo como resorte electoral.

En relación con el Estatuto se destacó que su culminación era una de las prioridades para la siguiente legislatura y que, a falta de la independencia, bueno era conformarse con lograr, después de 20 años, el desarrollo total del Estatuto. La paralización de tal desarrollo era una conculcación del Estatuto y de la propia Constitución ${ }^{36}$.

La independencia no apareció como objetivo político, sino como un futurible gustoso o apetecible, del que se habló en muy contadas ocasiones y, además, de pasada ${ }^{37}$. Preguntado Anasagasti sobre el giro al soberanismo de su partido, contestó: «No me gusta hablar de soberanismo; la palabra me parece una castaña» ${ }^{38}$. El candidato añadió: «...nosotros seguimos con el Estatuto y reivindicando su cumplimiento íntegro, cosa que todos los que se llenan la boca hablando del Estatuto y la Constitución no cumplen. Hemos hecho énfasis ahora quizás en un

\footnotetext{
35 Ver encuesta de Isabel de Bergaretxe: El Correo, 4-3-00, pp. 14-17.

36 Ver manifestaciones de Anasagasti en El Correo, 27-2-00 (40) y 7-3-00 (20). Ver, también, Deia, 27-2-00 (25).

37 Ver El Correo, 7-3-00 (20), y Deia, 10-3-00 (4).

38 El País, 6-3-00 (28).
} 
perfil más nacionalista, pero sabemos que la correlación de fuerzas es la que es y lo que queramos hacer lo queremos hacer con los votos, la palabra y la persuasión. Lo que no admitimos bajo ningún concepto son los modos y los tiempos de ETA y de $\mathrm{HB}{ }^{39}$.

Como era hábito electoral, las intervenciones relativas a los objetivos nacionalistas encubrían las posibles intenciones bajo palabras y conceptos, cuyo alcance no era descifrado. A las proclamas de que «con el Estatuto no nos conformamos» (Anasagasti) o de que «como vascos tenemos unos derechos» (Anasagasti) o de que Euskadi no estaría completa hasta que «no estuviera integrada por los siete territorios» (González de Txabarri) se sumaba la más confusa aún de que el Estatuto de Gernika tenía "posibilidades de seguir rompiendo costuras para que Euskadi sea más independiente, más europea y menos dependiente de Madrid» (Anasagasti) ${ }^{40}$.

Fruto del enfrentamiento electoral con ETA y EH vino la afirmación de Arzalluz de que «la territorialidad, la soberanía, la libertad, ése es también nuestro objetivo. El problema es qué métodos se utilizan para conseguirlo» ${ }^{41}$, donde el mensaje fundamental era el rechazo de la violencia y el desmarque electoral de EH y ETA, por lo que la soberanía no llegaba a ser más que un argumento orientado a las urnas.

Mayor utilización se hizo de la autodeterminación, bien de forma expresa o velada. Había que dejar a los vascos que decidiesen su futuro, de manera que «seguiremos siendo españoles o franceses si la mayoría así lo decide, pero sin ningún espadón y $\sin$ imposiciones» ${ }^{42}$. En el hipotético plebiscito de autodeterminación, que no podría celebrarse antes de 15 años y para el que habría que reformar previamente la Constitución, sólo debían participar los vascos que demostrasen vivir en Euskadi de una forma estable, «porque hay un porcentaje que, sin ser del País Vasco, está aquí y viene con su esquema de patria y de bandera ${ }^{43}$.

De la ponencia política del PNV se destacó «el legítimo derecho para decidir su futuro», que tenía el pueblo vasco, y la reivindicación del «reconocimiento de integridad territorial de Euskal Herria y el fomento de las relaciones entre las diferentes partes integrantes de nues-

39 Ibídem.

40 Deia, 10-3-00 (4); Deia, 9-3-00 (5); Deia, 11-3-00 (3).

41 Deia, 10-3-00 (4).

42 Palabras de Arzalluz: El Correo, 28-2-00 (23).

43 Palabras de Arzalluz: El Correo, 3-3-00 (20). Ver, también, en El Correo, 8-3-00 (24), las habituales palabras de Ibarretxe sobre la necesidad de «oír y respetar a la sociedad vasca». 
tro pueblo». La ponencia exigía procedimientos democráticos y el fomento de la colaboración entre todas las fuerzas políticas nacionalistas. El proyecto político con tales fundamentos estaba por desarrollar, pero, una vez hecho, debería «consolidarse jurídicamente sometiéndolo a consulta o referéndum popular» ${ }^{44}$.

La autodeterminación parece que era la forma de mostrar el respeto, que se merecía ese pequeño pueblo, que era el vasco, y de solucionar el problema político heredado desde hacía siglo y medio. Esta manipulación histórica se mezclaba con la no menor manipulación del mito de la nación (la palabra utilizada es «pueblo») en cuanto sujeto de decisión ad extra, aderezado este último con los ingredientes contrarios (de no menor manipulación) de la pequeñez, humildad, grandeza y poderío de la nación vasca. «No somos la aldea gala de Astérix y Obelix - dijo el presidente del partido-, somos un pequeño pueblo que quiere que se le respete, porque no es que seamos gente buena, es que a la fuerza no ha nacido nadie que pueda con nosotros ${ }^{45}$.

La petición del voto exigía moderación nacionalista y nada mejor que utilizar todos aquellos elementos, que eran comunes a fuerzas políticas distintas. Ni siquiera la autodeterminación era atributo exclusivo del nacionalismo. En lugar de independencia y soberanía política era más atractivo y rentable hablar de autonomía, de autodeterminación o de propuestas a favor de las selecciones vascas ${ }^{46}$, que se justificaron, por cierto, no como parte de un objetivo de soberanía, sino como algo basado en la Constitución, en el Estatuto y en la jurisprudencia del Tribunal Constitucional.

\section{Los contenidos no nacionalistas}

La defensa de la participación electoral al inicio de la campaña desveló unas expectativas, que no se moderaron a lo largo de la misma. Las

44 Gara, 29-2-00 (17). El País, 11-3-00 (26), recogía como objetivo del programa electoral la consecución del reconocimiento de la autodeterminación. Ver, también, Gara, 9-3-00 (16), donde González de Txabarri afirma que la última ponencia política aprobada está íntegramente en el programa electoral.

45 El Correo, 28-2-00 (23). Ver, también, El Correo, 1-3-00 (19).

46 Ver El Correo, 2-3-2000 (20), donde se informa del acto del PNV a favor de las selecciones vascas, al que asistieron varios jugadores del Athletic de Bilbao, para lo que hubo que adelantar la hora de entrenamiento. El País, 2-3-00 (5), informa ampliamente del acto, en el que el PNV prometió defender en la siguiente legislatura la competencia autonómica sobre el deporte, la derogación de la competencia de las federaciones españolas, la integración de las federaciones autonómicas en las organizaciones internacionales y la promoción de las selecciones autonómicas en los torneos internacionales. Ver, también, Deia, 2-3-00 (4). 
expectativas simplemente se desvanecieron con los resultados electorales. El esperado éxito electoral del nacionalismo, el del PNV y el de los catalanes y gallegos nacionalistas, obligaría a los candidatos popular y socialista a tener que contar con su ayuda para ser presidente del Gobierno. Los intereses vascos estaban, pues, en juego, y exigían la participación ${ }^{47}$.

La invocación de los intereses vascos era un argumento, expresa y continuamente utilizado contra el abstencionismo de EH, aunque tal vez sin mucha convicción, y que daba por supuesta la coincidencia de los intereses vascos con el éxito nacionalista ${ }^{48}$.

Como ejemplo de coherencia, Arzalluz defendía la presencia en Madrid, donde «estamos — como en Marte—», para defender los intereses vascos, a la vez que reconocía «algo de razón a Otegi», que decía que en Madrid no se conseguía nada. «Ni un duro. Esto es negociar en Madrid $»^{49}$, dijo el presidente del PNV. Ni un duro para el puerto exterior de Bilbao, ni para la terminal de carga de Santurtzi o el proyecto de túnel del Serantes, afirmó rotundamente.

Si bien se sugería que los apoyos parlamentarios podían ser muy complicados, si el PSOE no cambiaba de postura hasta el punto de arrastrar al PP en materia de pacificación, todo se hacía depender de los resultados electorales. La clave era electora ${ }^{50}$, pero, en cualquier caso, el PNV justificaba su participación para plantar cara en Madrid al «franquismo sociológico que actúa en democracia», que no podía ser otro que el que se ocultaba en el Partido Popular ${ }^{51}$.

Con la mirada puesta en el contexto nacionalista, Anasagasti sentenció que la mayoría podría votar con libertad, ya que EH había hecho una campaña pro abstención bastante suave («esa campaña de abstención y coacción activa de EH no se ha visto por ninguna parte ${ }^{52}$ ) y a pesar de que ETA condicionaba la libertad de voto. Pero la libertad de voto no había que confundirla con la utilidad del mismo. Votar a EA, socio del Gobierno Vasco en la anterior legislatura, era «echar 40.000 votos a la basura $»^{53} \mathrm{y}$, ya que el único grupo parlamentario con capacidad de hacer

47 En El País, 5-3-00 (1), se dice que el PP tendría que pactar con los nacionalistas de acuerdo con el sondeo de Demoscopia. González de Txabarri decía el mismo día que «la foto del día 13 será la del PNV, CIU y BNG» y que la Declaración de Barcelona sería clave para conformar los acuerdos de Gobierno (Deia, 5-3-00 (12)).

48 Ver El Correo, 25-2-00 (25): intervención de Arzalluz. Semejantes argumentos en Deia, 2-3-00 (5).

49 Gara, 1-3-00 (18).

50 Ver El Correo, 7-3-00 (20): entrevista a I. Anasagasti.

51 El Correo, 6-3-00 (18): intervención de Anasagasti en el mitin de Barakaldo.

52 El Correo, 9-3-00 (24).

53 El Correo, 10-3-00 (22). 
política y de presionar en Madrid era el PNV, había que votar en consecuencia. La petición del voto a los simpatizantes de EA se extendió también a los simpatizantes de EH. La victoria nacionalista del PNV sería por goleada, ya que se esperaba sacar siete escaños ${ }^{54}$.

La intervención del alcalde de Bilbao, I. Azkuna, llamando a los bilbaínos a las urnas después de condenar el atentado de ETA contra la Guardia Civil en San Sebastián, justificaba tal llamada en la necesidad de fortalecer la democracia para desterrar la violencia. La confianza en que la fortaleza de la democracia vencería a la violencia exigía la participación. El atentado en plena campaña atacaba «la confrontación libre y pacífica de ideas, el máximo exponente de la democracia ${ }^{55}$. Esta forma de argumentación del voto, cabe observar, se salía del criterio más utilizado por los nacionalistas.

El tema de la paz, el más ampliamente tratado de este apartado, volvió a situar al Pacto de Lizarra en el centro de la propaganda nacionalista, hasta el punto de que se puede decir que fue ampliamente utilizado (el tema de la paz) para poder justificar al Partido Nacionalista $\mathrm{y}$, especialmente, a su dirección, que habían quedado seriamente desautorizados con la renovación de los asesinatos de ETA.

Los dos comunicados del PNV ${ }^{56}$, que siguieron al funeral de Buesa y Díez y precedieron a la manifestación por los mismos, destacaron los

54 Ver El Correo, 11-3-00 (18). La participación electoral para garantizar los intereses vascos aparece, también, en Gara, 4-3-00 (22); Deia, 4-3-00 (4); Deia, 5-3-00 (4 y 5); El Mundo, 5-3-00 (10); Deia, 7-3-00 (4), donde se leen estas palabras del candidato Josu Erkoreka: «En la situación actual de Euskal Herria, los abertzales tienen la obligación de acudir a las urnas. Si fuésemos dueños de nuestro futuro y si en la bandera europea apareciese la estrella vasca como la de otro país cualquiera, cada uno podría elegir entre votar o no votar. Pero la verdad es que esto último no se ha conseguido aún, por lo que los aberztales de verdad debemos acudir a las urnas para así defender el futuro de Euskal Herria, ya sea en Madrid o en Bruselas»; Deia, 8-3-00 (4); Deia, 8-3-00 (5), defensa de las pensiones; Gara, 9-3-00 (16), donde González de Txabarri explica así la presencia del PNV en el Parlamento español: «La postura tradicional del PNV ha sido la de realizar política enraizados en Euskadi y, de alguna forma, teniendo los altavoces institucionales en aquellos foros en los que esa acción política vasca puede tener su influencia, su carga decisiva. Entendemos que el diseño básico de la actuación del PNV sigue siendo válido, moderno, funcional y, además, es el habitual en los comportamientos sociales que se producen aquí. El que tiene aquí una empresa busca ese mismo esquema de trabajo. Los planteamientos sociológicos, en estos momentos de fenómenos de globalización y enraizamiento, están planteando éste como el modelo a seguir tanto desde planteamientos empresariales como sociales»; en Madrid había que defender, incluso, la ponencia política, que propuganaba el nuevo marco jurídico; Deia, 9-3-00 (5).

55 El Correo, 8-3-00 (24).

56 Ver El País, 25-2-00 (19), y Deia, 25-2-00 (5). 
dos aspectos básicos nacionalistas sobre la cuestión de la violencia: la justificación del proyecto nacionalista, que no tendría ninguna modificación posterior, y la defensa de la dirección del partido ante los supuestos ataques de otros partidos, especialmente, el Partido Popular. A medida que la campaña se alejó de los asesinatos de Buesa y Díez, el recurso a presentar el plan nacionalista de pacificación aumentó considerablemente.

El tratamiento dado a la paz situaba a cada uno en su sitio. Al PNV en el centro de la virtud moral y política (el PNV «ha sido el único partido que se ha jugado el físico para conseguir la paz definitiva ${ }^{57}$, dijo Arzalluz); a ETA en un extremo en cuanto agente y responsable único de la muerte; y a los partidos contrarios al Pacto de Lizarra, especialmente a los populares, en el otro extremo, por rechazar el único remedio posible, el diálogo. Esta interpretación claramente la formuló el lehendakari, como luego se verá, cuando encomendaba al PNV la misión de acabar con las dos enfermedades presentes: la muerte en ETA y la falta de diálogo en los partidos políticos. La intervención de Anasagasti, que parecía salirse de la línea oficial, obligó a puntualizaciones y, tal vez, rectificaciones posteriores.

Ya de entrada el Pacto de Lizarra se justificó como consecuencia de la negativa de Aznar a mantener con ETA el «hilo caliente» que había tenido el ejecutivo de Felipe González. Arzalluz lo explicó de la siguiente manera: «Me mandó el PSOE a hablar con el señor Aznar para que juntos pudiéramos iniciar un camino hombro con hombro de solución. Aznar despreció esta oferta. Cuando vimos que se había roto aquello anterior y, viendo que se movían cosas en el mundo de ETA, empezamos nosotros por nuestra cuenta, después de anunciárselo al presidente del Gobierno» ${ }^{58}$.

Lizarra había surgido, pues, con el apoyo de «la mayoría absoluta de este país» ante la imposibilidad de crear una mesa de todos los partidos vascos. "Y si las mayorías - concluía Arzalluz- son de respeto, ¿cómo se puede entender el linchamiento que hubo de Lizarra? ¿Es que alguien se ha leído Lizarra? si es un papel muy simple, calcado de lo que dijo Ardanza» ${ }^{59}$.

El programa electoral destacaba que ETA era la única responsable de la violencia, cuya solución requería la vía de Lizarra, el acercamiento de los presos y un foro de diálogo entre todos los partidos favo-

\footnotetext{
57 Gara 6-3-00 (10).

58 El Mundo 29-2-00 (9).

59 El Mundo 29-2-00 (9).
} 
rables al uso exclusivo de los procedimientos democráticos ${ }^{60}$. Lo volvió a repetir el EBB, cuando, después de defender que la paz, la no violencia o el derecho a la vida eran lo primero, afirmaba la firme creencia en que el camino democrático y eficaz hacia la paz era el diálogo entre todos y no la estrategia de aislamiento, que conducía únicamente a la inflexibilidad y al enquistamiento de los problemas ${ }^{61}$.

Este último punto, se destacó, no era ninguna novedad, ya que entre los participantes del pacto de Ajuria Enea existía la convicción de que al final el problema se terminaría en una mesa de diálogo con concesiones por parte de unos y otros. Arzalluz, a quien se deben estas consideraciones, se refería a «unos y otros» enzarzados en la violencia en estos términos: «Ahora un golpe de uno; luego, de otro. ¿Para cuándo el diá$\log 0 ?{ }^{2} 62$.

Si bien la actuación de la policía «con toda su fuerza» era necesaria, ya que no se podía admitir que se asesinase o se secuestrase, no bastaba la vía policial para alcanzar la paz. Por ello el PNV pedía el voto a cuantos apostaban por el diálogo ${ }^{63}$. No otra cosa era el Pacto de Lizarra: un proyecto de paz, una oferta de paz. Lizarra no era la violencia, sino un instrumento para acabar con ella. Esta era la razón, se dijo con bastante imprecisión, por la que se tenía miedo al Pacto de Lizarra, porque era un proyecto de paz. Era el único foro para hablar sin exclusiones. No había otra alternativa, ya que nadie la había presentado. Arzalluz retaba a los partidos críticos con tal proyecto a que presentaran otra alternativa. En su opinión, Lizarra era la copia del camino seguido en Irlanda para solucionar problemas semejantes ${ }^{64}$.

El diálogo era el camino para acabar con la «guerra»; luego vendría la construcción nacional. Esta secuencia servía para atacar al PP por no dialogar y a EH por querer la construcción nacional sin la previa desaparición de ETA. «Nos dicen — dijo el presidente- que sólo queremos que desaparezca ETA, pero nosotros creemos que no se puede construir nada mientras se está en guerra... primero terminaremos con la guerra y luego construiremos ${ }^{65}$.

Ibarretxe insistió en la necesidad del diálogo: «Hay que hablar, hay que dialogar, pero no se puede matar; ...tenemos que respetar los derechos humanos, tenemos que respetar la vida, tenemos que oír y respetar

\footnotetext{
60 Ver El Correo, 1-3-2000 (22).

61 Ver Deia, 25-2-00 (5).

62 El Correo, 2-3-2000 (20).

63 Ver El Correo, 2-3-2000 (20) y 5-3-2000. Ver, también, Deia, 2-3-00 (5).

64 Ver El Correo, 4-3-2000 (24) y 8-3-2000 (20). Ver, también, El País, 6-3-00 (28).

65 Deia, 2-3-00 (5).
} 
a la sociedad vasca» ${ }^{66}$. La participación electoral debía servir para «acabar con los dos síntomas de la enfermedad que padecemos, la muerte y la falta de diálogo» ${ }^{67}$.

Con esta forma de argumentar, que unía la condena de la violencia con la defensa de un diálogo abstracto y el respeto a la sociedad vasca, estaban servidas, obsérvese, la justificación del PNV, para quien se pedía el voto, la condena de todos los demás actores y la tesis de que no podía haber, por definición, otra alternativa que no fuese nacionalista, es decir, que no estableciese a la sociedad vasca como ámbito de decisión (derecho de autodeterminación). Esto constituía la repetición del sentido del Pacto de Lizarra de que la única paz posible era una paz nacionalista, o sea, que acarrease el triunfo del nacionalismo. La tesis seguía siendo paz por nacionalismo.

Esta interpretación la confirmó Egibar, cuando en una conferencia en Pamplona especificó o concretó la abstracción habitual del término «diálogo», a la que más arriba me he referido, y las verdaderas condiciones del proceso de paz, que convertían en una mentira la llamada a todos para dialogar, porque el diálogo invocado por el nacionalismo excluía a los no nacionalistas. El ejemplo de la importancia del diálogo para la resolución de conflictos fue el relativo a la autovía de IrurtzunAndoain, «en el que hubo un modelo de resolución que costó, pero, al final, gracias al diálogo se abrieron puertas que estaban bien cerradas» ${ }^{68}$. Las condiciones excluyentes del proceso de paz, al que se llamaba a dialogar, eran «en primer lugar, el respeto a los derechos humanos de todas las personas, empezando por el derecho a la vida. El segundo sería dar cuerpo a ese deseo de dar la palabra a la sociedad vasca para que sus decisiones sean aceptadas» ${ }^{69}$. La consideración de la autodeterminación como una de las «vías sagradas» para consolidar un proceso de paz y, por tanto, del diálogo, es claro que invalidaba la defensa del derecho a la vida, que no puede estar ligado a ninguna condición previa. La oferta parecía en un principio generosa, porque a unos se les pedía que dejaran de matar (lo mucho) y a otros que reconociesen la autodeterminación (lo poco). Pero se trataba de un engaño y de un negocio nacionalista.

66 El Correo ,8-3-2000 (24).

67 El Correo, 11-3-2000 (18). Más ocasiones en las que se insiste en el diálogo en: Gara, 3-3-00 (22); Gara, 4-3-00 (22); Gara, 6-3-00 (9); Gara, 7-3-00 (17); Deia, 8-3-00 (12); Gara, 8-3-00 (12): dialogar sobre la Constitución, la autodeterminación o lo que quieran PP y EH, según Arzalluz.

68 Gara, 7-3-00 (17).

69 Ibídem. 
El consenso nacionalista sobre el camino de la paz parece que se rompió con la tardía entrada en escena de Anasagasti, si bien, en un principio, repitió el guión conocido, insistiendo en que el terrorismo necesitaba algo más que la utilización de la policía y la condena. Este algo más se refería al diálogo y a la profundización democrática (cosa que no se clarificó en qué consistía). «Sólo sentados alrededor de una mesa — dijo- será posible superar esta página negra en la historia de Euskadi... (...) Si la vía policial trajera la paz, nosotros apostaríamos por ella sin dudarlo, pero no es así. Le recuerdo que el diálogo propició año y medio sin atentados de ETA. Convivimos con ese otro terrorismo de la «kale borroka», pero en año y medio no hubo funerales y tocamos con la punta de los dedos la posibilidad de cierta paz. Todos debemos reflexionar por las razones que llevan al fin de esa situación y todos debemos analizar las vías para que la esperanza vuelva a nuestros corazones. En cualquier caso ETA es la única responsable de estas dos muertes (F. Buesa y J. Díez)...» ${ }^{70}$.

La afirmación de que el PNV estaba dispuesto a dar todo por la paz no se corresponde con la interpretación de «paz por nacionalismo», que se hace en este trabajo y en el anterior sobre las Elecciones Autonómicas de $1998^{71}$. Por ello, parecen demagógicas las palabras de Anasagasti, en las que se afirmaba que «se nos ataca (al PNV) por miedo, pero sólo queremos la paz, no mercadeamos ni traficamos con ella» ${ }^{72}$.

Las aparentes diferencias surgieron con la interpretación del Pacto de Lizarra. Anasagasti defendió en otra intervención que Lizarra no había sido un error, sino todo lo que el PNV pudo hacer. Con la metáfora tan utilizada del «movimiento» se defendía que la equivocación estaba en el inmovilismo, ya que el PNV había logrado con Lizarra (con el movimiento) que las elecciones de 1998 y 1999 se celebrasen sin muertos, a diferencia de lo que estaba ocurriendo en las Generales de 2000. Hasta aquí la interpretación era ortodoxa, pero el candidato por Bizkaia añadió que Lizarra no era ni un «dogma» ni una «camisa de fuerza» para el PNV y que quedaría «colgado de una brocha» en cuanto el lehendakari lograra reunir a todos en una mesa. Y, como si lo desconociese, añadió que si Lizarra «dice que no hay atentados, que haya más democracia y que el tema vasco es un conflicto histórico de naturaleza política, me encanta» ${ }^{73}$, palabras que en su conjunto sugerían que Ana-

70 El Correo, 7-3-2000 (20), entrevista a I. Anasagasti.

71 Ver mi trabajo «Elecciones al Parlamento Vasco de 25 de octubre de 1998», Revista Estudios de Deusto, vol. 46/2, julio-diciembre 1998, pp. 11-89.

72 Ibídem.

73 El Correo, 9-3-2000 (24). 
sagasti apoyaba las creencias básicas nacionalistas a la vez que consideraba que Lizarra no tenía futuro, ya que también manifestaría que después de las elecciones, y dada la actitud de $\mathrm{EH}$, todo tendría que replantearse $^{74}$.

Anasagasti estimó que las palabras de Otegi sobre el comunicado de ETA significaban el abandono de las vías políticas, o sea, que EH había «roto dicho pacto (el de Estella) al no desmarcarse de los atentados de ETA» ${ }^{75}$. Por ello anunció que, tras las elecciones, el lehendakari establecería contactos con todos los partidos para lograr la unidad de los demócratas e intentar nuevas alianzas de Gobierno.

La interpretación, sin embargo, de Egibar en respuesta al comunicado de ETA aparecido en Gara y Euskaldunon Egunkaria destacaba que el PNV estaba convencido de la validez de la estrategia iniciada y que no pensaba abandonar el foro a pesar de que no se habían cumplido los fines para los que había sido creado: acabar con la violencia e incorporar a HB a la democracia ${ }^{76}$. La apuesta del PNV por Lizarra se mantendría incluso en el caso de que cayese uno del PNV en un atentado de ETA. Así lo expresó Egibar al decir: «A menudo hemos dicho que, si por causa de la violencia cayera uno de nosotros, el partido debería continuar por el camino emprendido, porque no hay otra vía» ${ }^{77}$.

Dadas las interpretaciones que se hicieron de las palabras de Anasagasti en el sentido de que el PNV daba por roto el foro de Estella, Egibar intervino en dos ocasiones al día siguiente para aclarar que ni el PNV ni Anasagasti habían dicho nada semejante. Se trataba, simplemente, de una reflexión de su compañero de partido convertida en titular de los periódicos. Por contra, los principios de Lizarra — defensa de los derechos humanos y respeto a la palabra del pueblo vasco- estaban más vigentes que nunca. No sería el PNV el que abandonase ni Lizarra, ni Batera, ni Udalbiltza. El programa del partido recogía la validez del planteamiento y pensaba desarrollarlo después de las elecciones independientemente de los atentados de ETA y a pesar de que éstos lo atacaban frontalmente. La tregua había desarrollado espacios de colaboración entre los nacionalistas y el PNV no iba a permitir a ETA tirar al vertedero la ilusión y el trabajo desarrollado durante la

74 Ver El Correo, 11-3-2000 (24).

75 El País, 10-3-00 (23). Ver, también, Gara, 10-3-00 (18).

76 Ver El Corrreo, 9-3-2000 (30). Esta postura es inequívoca desde el comienzo de la campaña: El País, 25-2-00 (19); Deia, 25-2-00 (5).

77 El Mundo, 6-3-00 (9). Gara, 7-3-00 (17), también recoge la idea de que el PNV no abandonará Lizarra, porque es la única vía para la solución del conflicto. 
misma $^{78}$. Con ello el PNV se mantenía en la misma línea, que había defendido desde el asesinato de Buesa, es decir, la validez del Pacto de Lizarra y la estrategia de pacificación basada en el diálogo sin exclusiones y en el rechazo de la vía exclusivamente policial y del aislamiento social ${ }^{79}$.

Anasagasti explicó que él había invitado a la reflexión a todos los partidos para encontrar una salida a la situación y que en Madrid se habían empeñado en poner en titulares (la misma palabra utilizó Egibar) la supuesta ruptura del PNV, porque habían convertido «en una especie de Infierno de Dante» al foro de Lizarra ${ }^{80}$. «Para el PNV — destacó en el último día de campaña - el Pacto de Lizarra sigue vigente», aunque para él tanto Lizarra como Ajuria Enea estaban superados. Lo que asustaba de este acuerdo en Madrid era que profundizaba la «democracia ${ }^{81}$.

Esta última afirmación no era nueva. Ya ante la RTVE había dicho Anasagasti que lo que pedía el Pacto de Lizarra era «más democracia, no más nacionalismo» (interpretación que no puede sostenerse, sino de manera gratuita), por lo que no podía considerársele como «una especie de cámara de terror» ${ }^{82}$.

La explícita disparidad de criterios que suponía afirmar que el PNV haría en su momento una autocrítica, pero no «en campaña y en público», ya que «nadie se limpia los calzoncillos en público» (Anasagasti) ${ }^{83}$, no

78 Ver El Correo, 11-3-00 (24). La idea de que los atentados de ETA iban directamente contra el Pacto de Lizarra, contra las vías democráticas y el diálogo aparecía ya en el comunicado del PNV, que siguió al funeral de Buesa (El País, 25-2-00 (19)). El País, 11-3-00 (20), interpretaba que la intervención de Egibar corregía a Anasagasti, ya que los nacionalistas no iban a permitir a ETA que «arroje al vertedero la complicidad alcanzada y apague las luces de una ilusión». En Gara, 11-3-00 (16), Josoba Egibar dice: «EAJk ez ditu Batera, Lizarra-Garazi eta Udalbiltza utziko».

79 Ver El País, 25-2-00 (19).

80 Ver El Correo, 11-3-00 (24). Semejante imagen ya la había utilizado en Deia, 7-3-00 (5).

81 Deia, 11-3-00 (2), y El País, 7-3-00 (1). Sobre el sentido del Pacto de Lizarra ver: Gara, 4-3-00 (22); Deia, 4-3-00 (5): Lizarra, oferta de paz; Deia, 5-3-00 (5): Lizarra, método de trabajo; El País, 6-3-00 (28): Lizarra, una reunión como el Pacto de Ajuria Enea en su momento; Deia, 7-3-00 (5): Lizarra, pide más democracia, no más nacionalismo; El País, 6-3-00 (28): Lizarra, hablar con todos, incluso con Aznar; El Mundo, 6-3-00 (9): Lizarra, válido, aunque cayese uno del PNV; El País, 7-3-00 (1): Lizarra y Ajuria Enea, superados; Gara, 7-3-00 (17): Lizarra, «modelo de resolución del conflicto»; Deia, 8-3-00 (5): «Discutamos todos y de todo», eso es Irlanda y Lizarra; Gara, 8-3-00 (12): Lizarra, estrategia de paz, nada más; Deia, 10-3-00 (12): Lizarra, método para resolver un problema.

${ }^{82}$ Deia, 7-3-00 (5).

83 El País, 6-3-00 (28). 
permite interpretar al PNV como a un partido dividido, enfrentado o en pugna en un supuesto debate, que se posponía, por causa del Pacto de Lizarra y de su estrategia. Esto serviría para destacar la dimensión democrática interna del mismo. Más bien se trata de una maniobra electoral orientada a captar el voto no sólo de los que se identificaban con el contenido y estrategia de Lizarra, sino, también, el de aquéllos que lo criticaban e, incluso, lo rechazaban. Para éstos iban dirigidas las promesas de una autocrítica y del posible envío al desván de los trastos inútiles del Pacto de Lizarra. No había que perder la unidad del partido, pero, de momento y sobre todo, no había que perder la unidad del voto. El PNV no sólo era el Pacto de Lizarra. Era, también, la crítica y el rechazo del mismo. Y si no lo era, podía serlo. El debate no tenía fecha, pero el voto, sí.

El programa electoral:

- en materia de inmigración defendía la agilización de la resolución de las situaciones de irregularidad, la extensión de los servicios generales a la población inmigrante y el reagrupamiento familiar, además de destacar la necesidad de campañas de concienciación para evitar la discriminación y la xenofobia ${ }^{84}$;

- en materia de siniestralidad laboral culpaba a los poderes públicos del aumento de accidentes y, aunque advertía de los intentos de la Comunidad Autónoma del País Vasco por seguir políticas propias y eficaces, consideraba a la normativa estatal bastante rígida ${ }^{85}$;

- en materia de violencia doméstica apostaba, desde el punto de vista social y educativo, por programas de prevención, acogimiento y tratamiento psicológico no sólo para las víctimas, sino también para el maltratador ${ }^{86}$;

- en materia de autopistas pretendía incorporar las autopistas concesionarias del Estado a la red vasca y construir la autopista de peaje Urbina-Maltzaga ${ }^{87}$;

- proponía en relación con el agua aumentar los planes de saneamiento en las difererentes cuencas, intensificar la depuración de las aguas residuales, reforzar la inversión en abastecimiento y defensa contra inundaciones ${ }^{88}$;

\footnotetext{
84 El Correo, 25-2-2000 (26).

85 Ver El Correo, 26-2-2000 (27).

86 Ver El Correo, 27-2-2000 (41).

87 Ver El Correo, 28-2-2000 (24).

88 Ver El Correo, 29-2-2000 (20).
} 
- no desarrollaba propuestas concretas sobre la vivienda, ya que consideraba que se trataba de una competencia autonómica y no central, aunque consideraba la vivienda como una cuestión de prestación social, para lo que impulsaba planes de vivienda protegida ${ }^{89}$;

- promocionaba, en materia de fármacos, el uso de medicamentos genéricos, para una mejor utilización del gasto de los fondos públicos, y campañas informativas al respecto ${ }^{90}$;

- en materia de nuevas tecnologías defendía la creación de centros públicos de salas informáticas, el desarrollo de Internet en la educación y en la administración, la rebaja de los equipos informáticos, la consideración de Internet como servicio básico con tarifa plana y el fomento del comercio electrónico ${ }^{91}$;

- en cuanto al Impuesto sobre la Renta de las Personas Físicas (IRPF), proponía una rebaja fiscal, especialmente en los tramos de renta inferiores a tres millones de pesetas, y el reforzamiento del tratamiento de la familia en el impuesto con independencia de los ingresos ${ }^{92}$;

- en materia de Televisión pública defendía la reforma de los órganos de gobierno del Ente Público, la elección por el Parlamento del Director General y del Consejo de Administración, un modelo de financiación mixta y la adscripción de los centros regionales a los Parlamentos autonómicos ${ }^{93}$;

- en cuanto a las pensiones invitaba a la mejora de las mismas (v.g. equiparación de las más bajas con el salario mínimo) y al apoyo a las familias que atendieran a personas mayores discapacitadas $^{94}$;

- en materia de residuos optaba por la aplicación de la política europea en materia de gestión de residuos y por la elaboración de un marco legal, que permitiera una gestión eficaz de las basu$\operatorname{ras}^{95}$;

- proponía diversas medidas para aumentar la calidad de la atención sanitaria tales como la elaboración de un nuevo Plan de Salud, la disminución de las listas de espera, alternativas a la hos-

\footnotetext{
89 Ver El Correo, 2-3-2000 (22).

90 Ver El Correo, 3-3-2000 (22).

91 Ver El Correo, 4-3-2000 (25).

92 Ver El Correo, 5-3-2000 (29).

93 Ver El Correo, 6-3-2000 (22).

94 Ver El Correo, 7-3-2000 (24).

95 Ver El Correo, 8-3-2000 (22).
} 
pitalización tradicional, mejoras en la elección del médico y del centro y potenciación de la atención primaria ${ }^{96}$;

- proponía, por último, el cumplimiento de los compromisos adquiridos por la Administración central para la entrada en servicio de la nueva red ferroviaria vasca en velocidad alta y su ramal de conexión con Pamplona ${ }^{97}$.

\section{Futuro gobierno postelectoral}

Al comienzo de la campaña se utilizó el argumento de que el voto a los partidos nacionalistas, no sólo al PNV, podría influir en la designación del Gobierno. En este sentido se manifestó Arzalluz al asegurar que si los nacionalistas catalanes, gallegos y vascos obtuviesen suficientes representates, «ni Almunia ni Aznar serán presidentes sin la ayuda de estos especímenes tan denostados llamados nacionalistas» ${ }^{98}$. No era la única razón para pedir el voto, ya que éste también se justificaba para defender los intereses vascos allí donde estaban en juego, pero servía para magnificar ante los fieles la importancia del partido, que el futuro redujo a la nada.

Pero el argumento del partido bisagra apenas se volvió a utilizar o, al menos, no consta en la prensa que se utilizase frecuentemente. Hubo alusiones a posibles pactos postelectorales con los socialistas con miras a la paz $^{99}$, aun en el caso de que no obtuviesen la Moncloa, y hubo, también, el ofrecimiento de apoyo parlamentario a Almunia para que fuera presidente, aunque sacara menos escaños que Aznar, siempre y cuando presentara un planteamiento mejor que el del PP100. Justo a mitad de campaña Anasagasti pidió el voto exagerando el papel, que iba a corresponder a su partido, al decir que «nos jugamos el juego parla-

96 Ver El Correo, 9-3-2000 (29).

97 Ver El Correo, 11-3-2000 (23). El País, 11-3-00 (26), recoge resúmenes semejantes del programa electoral. También lo hace Deia.

98 El Correo, 25-2-00 (25). En Deia, 1-3-00 (4) se lee: «Aznar o Almunia tendrán que pactar con esa política (nacionalista) que tanto desprecian». En Deia, 10-3-00 (12) Anasagasti esperaba que el PP ganaría, aunque sin mayoría en el Senado, y deseaba que bien Aznar, bien Almunia, resolviera el problema vasco y desarrollara y ampliara el Estatuto de Gernika.

99 Ver El Correo, 29-2-00 (18), donde la apuesta, en palabras de Arzalluz, por consensuar fórmulas de paz con Almunia, aunque no llegase al poder, no excluía al PP, ya que se añadía «y sin el PP, si hace falta», y 9-3-00 (24). No se trata, por tanto, de pactos de Gobierno. Lo mismo aparece en El País, 29-2-00 (24).

100 Ver El Correo, 1-3-2000 (19). 
mentario ya que no habrá mayoría absoluta y tendrán que pactar. Nosotros estaremos allí para plantarles cara» ${ }^{101}$.

Algún comentario de prensa se refirió a estas cuestiones e interpretó el deseo inicial del PNV como el sueño de Arzalluz de realizar una alianza de los firmantes de la Declaración de Barcelona con el partido ganador para tener bajo su autoridad al Gobierno. Desaparecido el sueño y rota toda relación con el PP, el PNV estaría llamando a la puerta del Partido Socialista ${ }^{102}$.

\section{B) La crítica electoral}

\section{Partido Popular}

La obsesión por el PP revela quién era para el nacionalismo del PNV no precisamente el contrario, sino el enemigo político a batir en las elecciones. Como ya está escrito más arriba, más del $40 \%$ de cuanto se manifestó en la campaña tuvo a los populares como centro de los ataques más variados y despiadados. La intención de transmitir al electorado una sensación de miedo y temor ante el posible avance del PP parece manifiesta.

Destaca en primer lugar la identificación ideológica de los populares y los términos utilizados para ello. El Partido Popular fue tenido por antidemócrata y descrito con términos tales como «dictadura», «herederos del franquismo», «18 de julio», «Movimiento», «fachas», «hijos de la dictadura franquista» y «reaccionarios». La campaña comenzó con la afirmación de que era necesario volver a estudiar los años de la dictadura franquista para entender las maneras con las que venían algunos, que no eran otros que los populares ${ }^{103}$. En ellos se veía «la cara del "facha" y a los "herederos del régimen franquista"»" 104 . Era precisa-

101 Deia, 5-3-00 (5).

102 Ver El Correo, 1-3-2000 (18), R. Gorriarán, «Parejas de baile». Ver Deia, 5-3-00 (5), donde Anasagasti defiende la importancia de trabajar con catalanes y gallegos para demostrar que «estamos ante un Estado plurinacional, pluricultural y plurilingüe y para conseguir la transferencia de las competencias estatutarias».

103 Ver El Correo, 25-2-00 (25). El comunicado del PNV (El País, 25-2-00) dice tener la impresión de que en un Ministerio de Madrid quieren que se vuelva a la época de los guerrilleros de Cristo Rey con una organización más sofisticada y, por supuesto, contra el nacionalismo. Semejantes descalificaciones y otras, como la de llamarle a Aznar «Cid Campeador», en Deia, 29-2-00 (4); Deia, 4-3-00 (4); Deia, 5-3-00 (5); Deia, 8-3-00 (4 y 12); Deia, 10-3-00 (4 y 12): «Que Dios nos coja confesados», si el PP gana con mayoría cercana a la absoluta; el discurso popular es más bien de Blas Piñar; El País, 9-3-00 (24); El Mundo, 11-3-00 (10): «Signos de neofranquismo».

104 El Correo, 28-2-00 (23), palabras de Arzalluz en el polideportivo de Anoeta. Ver, también, El País, 28-2-00 (19). 
mente la «fachenda» que tenía detrás el PP la que le había impedido «moverse» durante la tregua ${ }^{105}$. Su pretensión, en unión con los socialistas y con determinados medios de comunicación, de fracturar la sociedad vasca llevaba a la exclamación de que «a veces dan miedo y parece que van a volver al 18 de julio, enseñándonos su verdadera cara: la de las mentiras, la de la manipulación... echándonos a todos los españoles encima, porque toda España está cabreada con nosotros» ${ }^{106}$, y a la explicación de que no existía en España un partido de ultraderecha como en Austria, «porque está incorporado al PP, y se deja sentir en la bien orquestada campaña para fomentar la fractura social» ${ }^{107}$. El PP era el partido de la derecha dura de toda la vida y no un partido de centro ${ }^{108}$.

Por todo ello, se le dijo a Aznar que «el franquismo con votos no (era) democracia» ${ }^{109}$ y que la firmeza democrática que exigía se contradecía con el supuesto hecho de no haber permitido juzgar a Pinochet y con el hecho de no haber condenado la dictadura de Franco ${ }^{110}$. La firmeza democrática de Aznar no era, en consecuencia, más que escaparate $^{111}$, y el posible triunfo electoral popular era toda una preocupación, porque con él volvían «los modos de Franco» ${ }^{112}$. La conclusión era clara: «Hay que evitar que el PP logre la mayoría absoluta»113.

A esta imagen acompañaba una retahíla de descalificaciones de los principales políticos del PP, especialmente, de Mayor Oreja, de quien se decía que era «capaz de estropear cualquier mesa (de diálogo) sólo por intereses personales, ni siquiera por intereses de su partido» ${ }^{114}$.

La política general popular fue atacada en dos puntos básicos, el informativo y el económico. En cuanto al primero, la acusación afirmaba que el Gobierno central ejercía un monopolio informativo con una tal unidad de criterio que asustaba al presidente del EBB. El Partido Popular

105 Ibídem.

106 Deia, 29-2-00 (4), exclamación de Arzalluz. Ver El Correo, 29-2-00 (18).

107 El Correo, 1-3-00 (19); intervención de Ochoa de Eribe en el mitin de Llodio.

108 Ver El Correo, 7-3-00 (20). En Deia, 1-3-00 (4), aparece la misma información acompañada de otras apreciaciones ya conocidas sobre la fractura social, el rechazo de la vía exclusivamente policial, o la defensa del «entendimiento de los vascos como único camino posible» de la paz.

109 El Correo, 1-3-00 (19); mitin de Llodio.

110 Ver El Correo, 5-3-00 (24).

111 Ver El Correo, 11-3-00 (18).

112 El Correo, 10-3-00 (22); ver también, El Correo, 25-2-00 (25).

113 El Correo, 10-3-00 (22), palabras de Anasagasti.

114 Deia, 3-3-00 (4), donde Arzalluz dice, además, que es «mucho mejor que no se siente (Mayor Oreja), porque en la Mesa de Ajuria Enea estuvo bastante tiempo y fue él quien la estropeó». Ver, así mismo, Deia, 2-3-00 (5). 
estaría creando una tal concentración de medios de comunicación que su resultado era la falta de democracia, porque «un país en el que desde el Gobierno se controlan los medios de comunicación no es un país democrático... la unidad de criterio a la que se está llegando es lo más parecido a la prensa del Movimiento» ${ }^{115}$. Por otra parte, determinados medios de comunicación colaboraban en la pretensión de dividir y fracturar a la sociedad vasca, como ya se ha dicho ${ }^{116}$. En cuanto al aspecto económico, se subrayó la concentración económica dirigida por los «amiguetes» del presidente del Gobierno central, en comparación de la cual, se decía, lo de Conde y De la Rosa era una broma ${ }^{117}$.

La utilización con fines electorales de todo lo relacionado con el terrorismo tuvo una extraordinaria gravedad. Arzalluz había realizado al diario mexicano Proceso unas declaraciones, que acusaban al PP en tal sentido. Las había hecho días antes de que ETA asesinara a Fernando Buesa y Jorge Díez. Una vez realizado el asesinato, declaró que «yo no sé exactamente lo que dije sobre el voto de la sangre, pero muy probablemente que el PP se estaba aprovechando de la situación de tragedia para sacar votos, y es verdad. Por tanto, si quieren descalificarme por eso, yo lo repito» ${ }^{118}$.

En la misma entrevista, en la que se realizaron tales declaraciones, se comparaba a Jaime Mayor con Vladimir Putin, «que ha hecho actos de terrorismo para provocar el horror de la gente», y se acusaba a José María Aznar de haber «utilizado el tema de ETA para sacar votos, y lo ha vendido a México y a Francia como una muestra de firmeza de España contra el terrorismo. Esta es la triste realidad, son los votos de la sangre» ${ }^{119}$.

La misma interpretación electoralista se hizo de la detención en plena campaña de José María Olarra, dirigente de Herri Batasuna, por presunta vinculación con el aparato de relaciones internacionales de ETA. Para el presidente del EBB se trataba de una intrusión en el tema electoral a favor del PP, ya que no se entendía la urgente detención por

115 El Mundo, 28-2-00 (8).

116 Ver El Correo, 28 y 29-2-00 (23); Deia, 3-3-00 (4) y 8-3-00 (5). Entre los medios de comunicación acusados están El Correo, El Diario Vasco, TVE, Antena 3 y Tele 5. En Gara, 29-2-00 (17), González de Txabarri se queja del tratamiento informativo de El Correo y El Diario Vasco, que hacía «muy difícil desarrollar una campaña electoral en igualdad de oportunidades». González de Txabarri añade que «si con estas informaciones (las referidas a la manifestación de Vitoria) quieren reflejar la realidad social de Euskal Herria, cualquier día pueden decir que todos somos mahometanos».

117 Ver El Correo, 2-3-00 (20).

118 El Correo, 3-3-00 (20); entrevista a Arzalluz. Ver, también, El País, 28-2-00 (19).

119 Ibídem; entrevista a Arzalluz. Lo mismo aparece en Deia, 3-3-00 (4). 
no tratarse de un miembro de un comando, sino de un dirigente de partido. «Todo el mundo sabe — añadió- a quién beneficia esta actuación», que, por otra parte, Anasagasti calificó de sospechosa ${ }^{120}$.

La concesión por el Consejo de Ministros de una medalla póstuma a la primera víctima de ETA, José Pardines, provocó las preguntas de «¿Por qué ahora? ¿Tenemos que empezar nosotros a poner medallas a todos los que lucharon contra Franco?» ${ }^{121}$.

Esta manipulación electoral y partidista del terrorismo cuadraba con las interpretaciones de que el Gobierno central y el sector duro del PP consideraban a ETA como una «úlcera que a veces sangra» y de que no interesaba a Aznar acabar con el supuesto problema vasco ${ }^{122}$.

No obstante todo lo dicho, el centro de la campaña nacionalista contra los populares lo ocupó la real o supuesta pretensión del PP de vencer, desalojar, machacar o aniquilar al nacionalismo. El argumento utilizado se refería explícitamente a una lucha contra el nacionalismo, aunque en ocasiones se habló de lucha contra los vascos. La política antinacionalista buscaría como instrumento principal de su objetivo el enfrentamiento y la división de la sociedad vasca.

Este recurso fue utilizado, según los nacionalistas, en la manifestación que siguió al asesinato de Fernando Buesa. La actitud del PP y, principalmente, del PSOE produjo polémica, división y crispación. En lugar de ir con la, supuestamente, pancarta integradora de Ibarretxe, prefirieron, actuando de mala fe, seguir una pancarta alternativa, que, como lo había hecho en una anterior manifestación EH, introdujo un elemento distorsionador ${ }^{123}$. La «deslealtad» de socialistas y populares a la convocatoria del lehendakari justificó, según Egibar, los gritos en apoyo de Ibarretxe como fruto de «una explosión emocional que obedece a un instinto normal» ${ }^{124}$.

No se trataba de un hecho aislado, sino de la aplicación de un plan, de un «diseño», realizado por las organizaciones estatales con la finalidad de fracturar la sociedad vasca. Egibar citaba como apoyo de su interpretación las palabras de Rosa Díez, en las que manifestaba que, si bien la sociedad vasca era una, se podía dividir desde la política, pala-

120 El Correo, 3-3-00 (26).

121 El Correo, 10-3-00 (22).

122 El Correo, 4-3-00 (24) y 8-3-00 (20); manifestaciones de Arzalluz. Lo mismo en Deia, 4-3-00 (5). Sobre terrorismo y electoralismo, ver: El País, 3-3-00 (21 y 40); El Mundo, 3-3-00 (17 y 30); Deia, 8-3-00 (12): ETA les viene bien.

123 Ver El Correo, 29-2-00 (18).

124 El País, 27-2-00 (19). 
bras que habían dejado a los nacionalistas «alucinados». Lo ocurrido en la manifestación, desde los anteriores gritos contra el lehendakari el día del funeral por Buesa y Díez, era obra de «artesanos de la manipulación», a quienes no gustó la respuesta recibida, porque «no creían que el PNV, otros partidos y formaciones sindicales pudiesen salir detrás del lehendakari como un solo hombre. Deben tomar buena nota de lo que sucede cuando se agitan determinadas pasiones y se pretende imputar responsabilidades a fuerzas democráticas» ${ }^{125}$.

Arzalluz no sólo insistió en la misma interpretación, sino que añadió que los agitadores profesionales contra el lehendakari estaban identificados y que todo ello puso a los nacionalistas del PNV «muy calientes», de manera que fueron a la manifestación «a por todas para que no se arrastrara el nombre del lehendakari». Esta interpretación concluía con la arrogante e innecesaria, por fuera de lugar, afirmación de que lo ocurrido demostraba que «nadie puede medirse en la calle con el PNV» ${ }^{126}$. La «embestida en toda regla» del PP contra el PNV demostraba que el «enemigo a batir ya no (era) ETA, sino el nacionalismo vasco» ${ }^{127}$.

La cuestión del riesgo de fractura social le dio a Ibarretxe la ocasión de dar consejos generales, que, dado el momento, iban dirigidos a populares y socialistas: «Debemos tener cuidado con la división política, porque si no se ataja a tiempo puede consolidarse en una división de carácter social» 128 .

La idea de que pudiera quebrarse la sociedad la superó I. Azkuna al asegurar que ya existía en ella la crispación. En su opinión, la división política y social era un hecho, que daba a ETA una «victoria moral». De ahí que pidiera a la clase política un esfuerzo sobrehumano para «unir riberas», ya que el enemigo era el terrorismo ${ }^{129}$.

125 El Correo, 29-2-00 (18). Ver, también, Deia, 29-2-00 (5); El País, 6-3-00 (28), donde Anasagasti afirma en una entrevista: «El éxito de un servicio secreto es que todo el mundo piense que es como el diablo, que no existe. Yo, que estoy en la Comisión de Secretos Oficiales, sé las partidas que se gastan para pagar una cosa y otra. A mí no me digan que los servicios secretos no existen. Nosotros sabemos que lo de Vitoria estaba organizado porque se pusieron debajo de las cámaras. Lo que pasa es que cuando se dicen ese tipo de cosas se ridiculiza a quien las dice, pero no se analiza si tiene o no razón. Estas cosas no son espontáneas. Llámese CESID, llámese Servicio de Información de la Guardia Civil, llámese tramas organizadas».

126 El Correo, 29-2-00 (18). En la misma página se da otra versión de las palabras de Arzalluz: «La militancia estaba caliente y fue a Vitoria a por todas, a que no se arrastrara a Ibarretxe». Ver, también, El Mundo, 29-2-00 (9).

127 Deia, 29-2-00 (4).

128 El País, 1-3-00 (30). Ver, también, Deia, 1-3-00 (22).

129 El País, 1-3-00 (30). 
A los objetivos de división social y repulsa del lehendakari, Anasagasti añadía la pretensión de humillar al nacionalismo, que de ser cierta, explicaría una respuesta, que confirmaba que la actitud del PNV en tal manifestación más estaba pensada para demostrar la prepotencia del PNV que para condenar a ETA o defender la paz. Según esto, en la manifestación de Vitoria «PP y PSOE querían contarse y, de alguna manera humillar al nacionalismo. Al ver que no ha sido posible, dicen que hemos organizado un Alderdi Eguna, cuando sólo hicimos una manifestación repudiando a ETA, diciendo que la sociedad quiere la paz y, sobre todo, que con el PNV no se juega» ${ }^{130}$.

Ya antes, con ocasión del funeral por Buesa y Díez, Arzalluz había acusado al Gobierno popular y al Cesid de agitar a los ciudadanos contra el PNV y el lehendakari. El País desmintió esta interpretación afirmando que ni eran espías del Cesid, ni eran militantes del PP, ni agentes secretos de Interior. Se trataba, según este diario, de dos ex militantes del ya desaparecido partido Euskadiko Ezkerra, cuyos nombres daba el periódico, que fueron los que hicieron y repartieron los carteles en los que se pedía la dimensión de Ibarretxe. Lo manifestado por el presidente del PNV coincidía básicamente con el contenido del comunicado del partido, que extendía la responsabilidad del Gobierno, del PP y del Cesid a algunos medios de comunicación, cuya finalidad última era «trasladar la discusión y hasta la crispación política a una crispación y división social». Los mensajes de esta supuesta conspiración eran la dimisión de Ibarretxe, el ataque a la dirección nacionalista y su sustitución. Según la nota, con todo ello se pretendía «identificar en el mismo plano al terrorismo, con la dirección nacionalista y con el lehendakari» ${ }^{131}$.

${ }^{130}$ El Correo, 29-3-00 (18). En Deia, 29-2-00 (4) Anasagasti dice que «lo único que querían hacer (populares y socialistas) era humillar al nacionalismo en lugar de manifestar el dolor por el asesinato de Buesa y su escolta».

131 El País, 25-2-00 (19). El texto del comunicado decía: «EAJ-PNV quiere denunciar la irresponsabilidad que supone, por parte del PP fundamentalmente con la colaboración del Gobierno español, de algunos medios de comunicación bajo su control, y de funcionarios públicos principalmente, el montaje que han organizado estos dos últimos días en Vitoria-Gasteiz con motivo de los asesinatos de Fernando Buesa y Jorge Díez Elorza. Actos de protesta como el de ayer no se improvisan. Ni los carteles, ni el llevar megafonía, ni los movimientos de gentes, ni los autobuses con distintas procedencias. Lo mismo que ocurrió cuando el asesinato de Miguel Angel Blanco, que fue cuando comenzaron a acuñarse nuevos eslóganes como el de «ETA, no; vasco, sí», cuyo autor fue el CESID, como es autor de muchas otras actividades de agitación ciudadana en el País Vasco. Existe la impresión de que hay intencionalidades ubicables en un ministerio de Madrid, de que quieren que se vuelva a la época en la que los guerrilleros de Cristo Rey campaban a sus anchas, aunque 
La inclusión del rechazo de ETA y del apoyo a la paz entre los objetivos del PNV en la manifestación, no quita la fundada sospecha de que el PNV buscaba antes que nada salir airoso de un momento crítico, es decir, defender su propio interés por encima de todo. Para ello, en lugar de presentarse como el partido responsable de la política vasca en el Gobierno, no duda en ponerse en la situación del agredido y atacado que no puede hacer otra cosa que defenderse. Ni siquiera se reconoce a populares y socialistas otra finalidad que no sea la de derrotar al nacionalismo. Las palabras de Arzalluz de que intentaban «echar la ira popular sobre nosotros, como si fuéramos los que habíamos puesto la bomba» ${ }^{132}$, demuestran el recurso a la dramatización y a la persecución para justificarse ante los suyos y mantener el ideal y la unidad del partido.

Al margen de lo ocurrido en Vitoria, el argumento de la división y el enfrentamiento sociales fueron utilizados durante toda la campaña. Ya está escrito que según la interpretación nacionalista existía un plan diseñado para fracturar a una sociedad vasca, que hasta el momento permanecía unida, cuyo último objetivo era el mismo que tenía HB, desplazar al PNV. Lo dijo González de Txabarri con algún epíteto de epopeya, cuando afirmó que los objetivos de Mayor Oreja eran los mismos que los de HB, «desplazar al PNV (...) poder decir que hemos vencido a estos vascos indomables» ${ }^{133}$.

Con unos u otros destinatarios concretos al final siempre estaba el PP como responsable del proyecto de división social contra el nacionalismo. Ochoa de Eribe lo utilizó contra Mayor Oreja haciéndole responsable de «intentos denodados y horrendos por llevar a la sociedad a una fractura que no se percibe». La extrema derecha española, presente en el Partido Popular, se dejaría «sentir en la bien orquestada campaña para fomentar la fractura social» ${ }^{134}$. El presidente del partido añadió:

la organización actual es mucho más sofisticada y con muchos más medios. De las cadenas y de los bates de béisbol se ha pasado a operativos de manual de agit-prop (agitación y propaganda), intentando trasladar la discusión y hasta la crispación política a una crispación y división social. Hay dos mensajes perfectamente diáfanos y novedosos. Uno es la dimisión del lehendakari que empieza a formularse de manera interesada el martes por la tarde, que es secundado inmediatamente por medios de comunicación, y otro que se produce ayer, como reflejo de año y medio de estrategia, que es el ataque a la dirección nacionalista y la exigencia de un cambio, argumentos repetidos hasta la saciedad por el PP. Con esto se pretende identificar en el mismo plano al terrorismo, con la dirección nacionalista y con el lehendakari». Parte de este comunicado aparece, también, en Deia, 25-2-00

(5). Ver, también, El Mundo, 25-2-00 (1 y 3), y Gara, 25-2-00 (16).

132 El Correo, 3-3-00 (20) y Deia 3-3-00 (4).

133 El Correo, 28-2-00 (23). 
«Están intentando que la agresividad baje al pueblo; quieren dividirlo» 135 .

Arzalluz reconocía la división política existente, pero acusaba al PP y a los socialistas de tratar de llevarla a una sociedad, que no la padecía. Por ello se sentía preocupado de cómo iba a influir en la gente sencilla el mensaje de la "campaña de la "maleta" para conseguir una mayoría españolista y convencer al pueblo de que si ganamos los nacionalistas les vamos a echar» ${ }^{136}$.

Aquí estaba, hay que subrayarlo, el sentido de la preocupación por la fractura social, ya que en una sociedad dividida y enfrentada no cabía el sueño o proyecto nacionalista.

Conocida la postura del PNV de que la solución del problema de ETA requería la negociación, sin más aclaraciones, y conocida, también, la opinión de Aznar, manifestada, una vez más, en plena campaña, de que Lizarra era un gran error y que algunos tenían el «cuajo» de no ponerse del lado de las víctimas, sino de mantenerse donde estaban después de los últimos asesinatos, la explicación nacionalista del rechazo de la negociación centraba la respuesta, otra vez, en el nacionalismo. El Gobierno central temía que la negociación con ETA fortaleciese al nacionalismo y, de este modo, ayudara a la independencia del País Vasco ${ }^{137}$. No era, pues, la paz el objetivo del Partido Popular, sino evitar al precio de la paz el triunfo del nacionalismo. Precisamente, porque a Aznar no le interesaba acabar con el problema vasco, se dijo con gran atrevimiento que el PNV había roto por ello con el PP en la anterior legislatura ${ }^{138}$.

Otra vez Mayor Oreja fue el centro de las críticas nacionalistas al manifestar Ibarretxe que había que desenmascarar a los que querían dividir a los vascos y al explicar, con palabras habituales en él, que buscaban la división por miedo a que los vascos se pusieran de acuerdo y definieran el camino que querían seguir ${ }^{139}$. Ya lo había dicho Egibar en Andoain: "Al Estado no le da miedo un escenario en el que ETA actúe, le preocupa el escenario desde el 18 de septiembre. Lo que el Estado ha percibido en este último año y medio ha sido que "si aquí paran las armas y los abertzales empiezan a construir un camino, no podremos

${ }^{134}$ El Correo, 1-3-00 (19). Ver, también, amplia información en Deia, 1-3-00 (1, 4 y 5).

135 Deia, 2-3-00 (5).

136 Deia, 1-3-00 (4). Ver, también, El Correo 2-3-00 (20).

137 Ver El Correo, 4-3-00 (24).

138 Ver El Correo, 8-3-00 (20).

139 Ver El Correo, 5-3-00 (24). 
controlar eso". Está claro que lo que de verdad es peligroso e incontrolable para ellos es que todos los abertzales comiencen a participar en el juego político» ${ }^{140}$. Estas palabras, más las que le dirigió Arzalluz a Mayor - «descalabra a su vecino de una pedrada y se pone él la venda»respondían, en concreto, a la acusación del ministro del Interior de que Arzalluz dividía a su partido y estaba intentando hacer lo mismo con la sociedad vasca ${ }^{141}$.

Pocos días más tarde Ibarretxe repetiría su tesis, pero con la variante de sustituir el término «vascos» por el de «nacionalismo». A Mayor Oreja «le importa menos ETA que el hecho de que el nacionalismo pueda trabajar junto en un escenario sin violencia» ${ }^{142}$, repetiendo así la misma interpretación que Egibar.

Parece claro que el preocupado era el lehendakari y, en este caso, no precisamente por la ausencia de unidad en la sociedad vasca, sino por la fractura nacionalista. La dimensión social de la fractura política de la sociedad vasca era de una tal evidencia desde el Pacto de Lizarra (lo reconoció el mismo alcalde de Bilbao) que resultaba ocioso o necio decir que podía producirse lo que ya era un hecho. La preocupación parece que estaba en la prolongación de la división nacionalista, que negaba la esencia de la estrategia de Lizarra, la de un nacionalismo unido, visto cómo la única fórmula de conseguir los objetivos del nacionalismo.

La supuesta obsesión popular ante la demostrada imposible unidad del nacionalismo llegó hasta el final de la campaña, cuando se declaró que en Madrid no preocupaba ETA, sino lo contrario, es decir, que dejara las armas y ello permitiese hablar a todos ${ }^{143}$.

La interpretación de que interesaba al PP la permanencia de una ETA moderada o controlada contrastaba radicalmente con la acusación ya conocida de que los populares, sobre todo, Aznar y Mayor Oreja, querían la victoria policial sobre ETA y no su desaparición por el diálogo. Lo dijo de manera diáfana Arzalluz: «En cuanto han visto allí, en casa de Aznar, que nosotros podíamos arreglarlo, nos han machacado. No querían la paz por este camino, por el del diálogo, sólo entienden el de la rendición» ${ }^{144}$.

La intervención electoral de Mayor mentando la división del PNV, es decir, el resultado de la política marcada por el presidente del EBB,

140 Gara, 1-3-00 (18).

141 Ibídem.

142 El Correo, 9-3-00 (24). También, Deia, 9-3-00 (4).

143 Ver El Correo, 11-3-00 (18). La intervención textual de Arzalluz decía: «En Madrid no preocupa ETA, sino que deje las armas y podamos hablar todos».

144 Gara, 6-3-00 (10). 
provocó una reacción no ajena al misterio y al secretismo. Según Arzalluz, la repuesta expresa a semejantes acusaciones se haría después de las elecciones y en las instancias propias del partido; de momento era suficiente manifestar que "hay cosas que todavía no sabéis y tampoco las quiero decir en período electoral. Las diremos después en las asambleas». No obstante este comienzo, sí era verdad que alguien estaba intentando romper el partido, pero ese tal no era su presidente. La militancia debía observar «cómo se cotiza hoy en la "bolsa gubernamental de Madrid" al disidente. Cómo los buscan, los sacan e intentan incidir ahí». Arzalluz - suyas eran estas palabras - insinuaba conocer a quienes intentaban la división en el PNV y los procedimientos utilizados. «...vamos sabiendo cosas - concluyó-, aunque no tengamos un servicio de información por ahí» ${ }^{145}$.

El tema de la unidad social fue un tema tan electoral que todos los propagandistas nacionalistas lo tocaron. La pregunta dirigida a Anasagasti sobre si había riesgo de fractura social fue respondida de una manera, que negaba la evidencia de que la praxis de la violencia era selectiva social y políticamente, de la cual se derivaba la mayor fractura social y política posible de Euskadi, aquélla que negaba a unos ciudadanos la vida, libertades y propiedad, que reconocía o toleraba a otros. La identificación, por otra parte, de la lucha por el poder que define a cualquier partido político con la fractura social o desprestigio de las instituciones raya en el rídiculo más absurdo. Según el candidato del PNV, «en Euskadi no hay dos sociedades. Hay una única sociedad castigada por el recurso a la violencia de una minoría. Cuando ETA desaparezca, la unidad será más perceptible. Sólo quienes como el PP organizan campañas contra las instituciones para desalojar al PNV trabajan por la fractura, pero fracasarán porque la vasca es una sociedad madura que sabe lo que quiere y que está acostumbrada a superar momentos difíciles» ${ }^{146}$.

El diálogo y el entendimiento, sin violencia, entre nacionalistas, que el PP trataría de evitar a toda costa, sin importarle, incluso, la permanencia de ETA, era la muestra de la política nacionalista seguida antes y después de Lizarra ante la violencia y la paz. Exactamente era la

145 El Correo, 5-3-00 (24).

146 El Correo, 7-3-00 (20), entrevista a I. Anasagasti. Arzalluz había dicho que no podrían dividir al pueblo vasco, porque «todo el que vive aquí sabe que eso es mentira» (Deia, 2-3-00 (5)). Más lugares sobre el intento popular de acabar con el nacionalismo en Deia, 5-3-00 (4 y 5): «Atacar al nacionalismo debe unir al españolismo y poner en pie a todos los fachas» (Anasagasti); «no podemos consentir que el PP divida a la sociedad vasca y que además, culpe de ello al PNV» (Anasagasti); El País, 6-3-00 (28); Gara, 6-3-00 (10). 
antítesis de la estrategia popular ante los mismos problemas. Estas interesadas interpretaciones nacionalistas destacaron el inmovilismo del PP ante ETA en diversas intervenciones y, especialmente, en un «vídeo» del PNV para los espacios gratuitos en televisión, que también se pasó ante la concurrencia en el mitin de Anoeta, concurrencia que recibía la presencia de los populares en el «vídeo» con insultos y gritos de ;fuera!, ;fuera! y que guardó silencio ante la presencia de algún miembro de EH. El inmovilismo popular, es decir, la negación del diálogo, se contraponía con las actuaciones nacionalistas (las de Lizarra), y consistía en la utilización exclusiva de la vía policial ${ }^{147}$.

La búsqueda de la paz a través de la exclusiva vía policial mereció comentarios, que, además de afirmar que Aznar no valía para gobernar, ponían en duda su legitimidad y la de su Gobierno para considerarse defensores del Estado de Derecho y del imperio de la ley por cerrarse, precisamente, al diálogo y no aplicar, además, la ley de la misma manera a ETA y al GAL. Este brillante razonamiento de Arzalluz compitió con el ya conocido de Ibarretxe, que se preguntó cómo podía Aznar pedir firmeza democrática, cuando él no había permitido juzgar al genocida de Pinochet, ni su partido había condenado la dictadura franquista.

La conclusión nacionalista de la naturaleza y estrategia populares ante la paz, que mezclaba lo políticamente discutible con lo falso, se manifestó con toda claridad en el mitin de Vitoria: «Si alguien cree que lo que necesita la paz es más tricornios, más ertzainas, más cárcel, más torturas o más franquismo, que vote al $\mathrm{PP}{ }^{148}$.

La paz requería, lo sabemos, diálogo y negociación. Por ello, y a diferencia de Aznar, Ibarretxe estaba dispuesto a dialogar siempre con todos, incluso, con «un presidente español», porque sólo con el diálogo se podía encontrar salida a la violencia. Sin embargo, Aznar debía cumplir alguna condición para poder dialogar, la de «mantener una actitud diferente a la que ha mantenido sobre el proceso de paz, moverse, abandonar ese inmovilismo ciego que ha tenido durante mucho tiempo» ${ }^{149}$. La actitud popular, que abarcaba, incluso, la dura política seguida en el acercamiento de los presos, era una «barbaridad», que había

147 El País, 25-2-00 (19) ya recogía las declaraciones de Egibar y Arzalluz al comienzo de la campaña, que presentaban a Aznar obsesionado por enterrar el Pacto de Lizarra.

148 El Correo, 5-3-00 (24); son palabras de Arzalluz. Ver, también, en el mismo sentido de rechazo de la estrategia exclusivamente policial y de aislamiento social: Deia, 25-2-00 (5); El Correo, 28-2-00 (23), 1-3-00 (19), 2-3-00 (20); Gara, 5-3-00 (6).

149 El Correo, 6-3-00 (18). 
deteriorado la relación política y personal con Aznar, según Anasagas$\mathrm{ti}^{150}$.

Arzalluz, que consideraba justo tomar ejemplo de lo que se había hecho en otros sitios en materia de procesos de paz para recorrer «el mismo camino», refiriéndose con una interpretación engañosa al caso de Irlanda del Norte, retaba a que presentaran otra alternativa distinta a la que había seguido el PNV151.

La intransigencia del Gobierno del PP y el poco interés o confianza de Aznar durante la tregua explicarían estas disparatadas declaraciones de Anasagasti, en las que, una vez más, se trataba de justificar al PNV y evitar toda posible responsabilidad ante el fracaso de Lizarra: «La paz es prioritaria, es un problema de la sociedad con el Gobierno central y vimos que en el Ministerio de Interior, en algo que podría ser menor como el acercamiento de los presos, por parte del PP se mantienen posturas insospechadamente duras. Aznar no pone toda la carne en el asador, hasta el punto de que nos obliga a salir a la calle compartiendo una pancarta con $\mathrm{HB}{ }^{152}$.

El PNV parecía explicar la enorme atención prestada al PP durante la campaña por los intentos de éste de atacar y demonizar al nacionalismo para, así, tapar su fracaso de no haber aprovechado el tiempo de la tregua. Curiosamente, Arzalluz dio esta explicación, después de haber calificado al PP de facha y franquista, y la redondeó al interpretar el pacto de la anterior legislatura con el PP como un engaño y una utilización del PNV, que no se volvería a repetir ${ }^{153}$. Si Arzalluz hablaba de engaño y demonización, Anasagasti acusaba a Aznar de decir que el PNV prefería la Europa de Kosovo a la del Euro o de compararlo con Haider; en definitiva, de machacar al PNV ${ }^{154}$.

No se quedó atrás Ibarretxe en destacar al PNV en cuanto víctima de la persecución del Partido Popular, al acusar a Aznar de haber convertido a los nacionalistas «en los apestados del nuevo milenio» o al

150 Ver El Correo, 7-3-00 (2).

151 El Correo, 8-3-00 (20).

152 El Correo, 7-3-00 (2), entrevista a Anasagasti. Sobre el inmovilismo del PP ver: El País, 6-3-00 (25); Gara, 6-3-00 (10); El Mundo, 6-3-00 (9); Deia, 8-3-00 (5); Deia, 11-3-00 (2); Gara, 11-3-00 (16).

153 Ver El Correo, 28-2-00 (23) y 11-3-00 (18). Anasagasti declaró que Aznar había cumplido la primera parte del acuerdo de investidura (formación continua, renovación del Concierto, telefonía y devolución del patrimonio), pero no la segunda parte, la que afectaba al desarrollo del Estatuto de Gernika (El Correo, 28-2-00 (40) y 7-3-00 (20).

154 Ver El Correo, 7-3-00 (20). 
calificar de mentira, barbaridad e indecencia política (en dos ocasiones) la afirmación de Mayor Oreja de que había un reparto de papeles por el que ETA mataba y el PNV votaba ${ }^{155}$, afirmación que Arzalluz radicalizaba al decir: «nos han utilizado, han perseguido sistemáticamente el descrédito del lehendakari en el Parlamento vasco y han lanzado el mensaje de que el PNV está dominado por ETA» ${ }^{156}$.

Arzalluz, que ya había calificado la campaña popular de los primeros días de «sucia, baja y mísera» y advertido de que tenía por objetivo acorralar al nacionalismo ${ }^{157}$, repitió al final que la campaña, efectivamente, había sido sucia, porque al PP le valía todo, incluso el insulto y la mentira, nada parecido a lo que en los primeros años de la democracia había sido el comportamiento de UCD ${ }^{158}$.

La conclusión de esta obsesión por el Partido Popular era que el PNV, escarmentado de su relación anterior, no volvería a poner la otra mejilla. Esta pretensión de Arzalluz de presentar al PNV como el inocente ultrajado venía confirmada por la afirmación de que su presidente se honraba de que el PNV fuese el enemigo oficial del Gobierno ${ }^{159}$.

155 Ver El Correo, 9-3-00 (24) y 11-3-00 (18). Lo que Mayor Oreja había manifestado en El Mundo, 8-3-00 (23), era lo siguiente: «El acta del pacto no es lo que se redacta en Estella, sino que se refleja en el comunicado de ETA del 16 de septiembre de 1998. En ese acuerdo hay un cese indefinido y por parte de los demás existe el acuerdo de optar por la ruptura y la autodeterminación. Y ETA no miente. ETA será cruel, trágica, bárbara, asesina, pero no miente en sus comunicados. El comunicado era muy claro: guerra política a España y Francia, y como contrapartida, el cese indefinido. Cuando se ve que ese frente no tiene fuerza para sustituir a ETA, la fórmula posterior es: ETA a matar y el PNV a votar. El PNV trata de representar a Estella en las urnas. Hasta que el PNV no rompa ese acuerdo blindado con ETA tenemos los demás el derecho y la obligación democrática de denunciar que ahí se está produciendo un reparto de papeles».

156 El Correo, 11-3-00 (18). Más testimonios nacionalistas sobre la identificación, supuestamente hecha por los populares, entre nacionalismo y violencia en: Deia, 4-3-00 (4); Gara, 5-3-00 (6); Deia, 5-3-00 (5 y 12); El Mundo, 6-3-00 (9); Deia, 8-3-00 (4 y 12); El Mundo, 11-3-00 (10). Otros supuestos ataques al PNV en: Deia, 5-3-00 (5 y 12); El País, 6-3-00 (28); El País, 7-3-00 (5); Deia, 8-3-00 (12): el PP ataca al PNV, porque éste es el estructurador del País Vasco.

157 El Correo, 1-3-00 (19). En Deia, 2-3-00 (5), Arzalluz dice contra los populares: «Está siendo una campaña sucia, pero que no crean que vamos a echar la toalla tan pronto».

158 Ver El Correo, 11-3-00 (18). Anasagasti la calificó de «desmesurada, poco ética y tensionada» (Deia, 1-3-00 (5)); campaña de «prensa única y basada en el autoritarismo», campaña sucia que el Gobierno usaba para tapar problemas como los de El Ejido (Deia, 2-3-00 (5)). González de Txabarri afirmó que el juego sucio de populares y socialistas rebasaba «todo modelo de confrontación electoral» (Deia, 29-2-00 (5)).

159 Ver El Correo, 11-3-00 (18) y 2-3-00 (20). 


\section{Euskal Herritarrok y ETA}

La interpretación de que Euskal Herritarrok estaba sometida a los dictados de ETA fue explícitamente manifestada tanto al comienzo como al final de la campaña ${ }^{160}$. En este sentido, González de Txabarri llegó a calificar a Otegi de «gato domesticado por ETA» ${ }^{161}$. Frecuentemente, por otra parte, las alusiones a EH incluían expresas referencias a ETA, y, aunque no se les tenía por idénticos, sí se les consideraba de manera explícita o tácita suficientemente ligados como para ser tratados de manera conjunta.

A pesar de que EH no se presentó a las elecciones, el binomio EHETA ocupó el segundo lugar en la atención del PNV con un 28,61\% de la crítica y un $20,10 \%$ del total de la campaña.

En relación a EH, hubo, de principio a fin de la campaña, un constante rechazo de su actitud abstencionista. La abstención, interpretada o valorada de diversas maneras, fue el argumento más utilizado contra EH. La misma tenía dos dimensiones, la ausencia de candidaturas de EH a las Cortes, por un lado, y, por el otro, la campaña orientada a pedir y justificar la abstención del electorado.

La primera condena de la abstención se basaba en la necesidad de defender los intereses «vascos» allí donde fuere menester, ya que de lo contrario el lugar abandonado lo ocuparían otros ${ }^{162}$. Este argumento lo mismo servía para desprestigiar a EH por el abandono de tales intereses que para, todo lo contrario, destacar la responsabilidad del PNV, aunque, dicho sea de paso, no era un argumento políticamente nacionalista, que considera todo superfluo, si no se da la libertad nacional.

Egibar destacó otros argumentos contra la abstención y contra la campaña de abstención de EH, que Otegi calificó de solemne tontería y falta de respeto. Para el portavoz del PNV, la decisión abstencionista había sido impuesta por ETA. Por ello, pedía a los simpatizantes de EH que reflexionasen sobre tal decisión carente de libertad. Además, «no se sabe, —añadió-, con qué proyección en el tiempo, (ETA) pretende seguir compatibilizando violencia y política». Esta pretensión era imposible. La construcción nacional de la sociedad vasca no era factible,

160 Ver El Correo, 26-2-00 (26), palabras de Egibar; 28-2-00 (23), intervención de González de Txabarri en Anoeta, y 10-3-00 (27), manifestaciones de I. Anasagasti. También, ver Deia, 8-3-00 (12): «Estructura absolutamente dictatorial»; El País, 10-3-00 (23): «Absolutamente sometida y tutelada por una organización terrorista»; Gara, 10-3-00 (18).

161 El Correo, 28-2-00 (23).

162 Ver El Correo, 25-2-00 (25), manifestaciones de Arzalluz; El País, 28-2-00 (19); Gara, 28-2-00 (13). 
ni social ni políticamente, si se utilizaban los métodos de violencia e imposición. Por otra parte, la llamada al electorado a la abstención se contradecía con lo que durante año y medio se le había dicho por parte del nacionalismo: la necesidad de la participación y de la negociación ${ }^{163}$.

De nuevo unas manifestaciones de Arzalluz sobre el mismo tema dejaron manifiesta su lógica, al considerar que Euskal Herritarrok estaba actuando políticamente con toda «corrección», a pesar de que su censurable abstencionismo ponía «el triunfo en bandeja al ministro de la guerra» ${ }^{164}$. González de Txabarri había matizado que los objetivos de Herri Batasana coincidían con los de Mayor Oreja, porque ambos buscaban el desplazamiento del PNV, es decir, la victoria sobre los «vascos indomables» del PNV. En esta interpretación, EH o HB no trabajaría en beneficio del PP, sino en su propio beneficio, planteando con ello una cuestión de hegemonía o dirección del nacionalismo en general $^{165}$. La interpretación de González de Txabarri dificultaba la estrategia de Arzalluz y sus compañeros de campaña de presentar el problema político vasco como una cuestión contra el nacionalismo, ocultando su, también, dimensión intranacionalista.

La idea fue repetida al día siguiente. Se censuró a EH por la abstención, que ayudaba, «como siempre», a Jaime Mayor Oreja, y en esta ocasión, además, por llevar a los nacionalistas «a las cumbres con proyectos que no tocan tierra», afirmación que no encajaba con la idea de política correcta del día anterior. El presidente del EBB, después de recordar a Otegi que mientras éllos habían «andado al tiro, nosotros hemos estado trabajando», defendió el argumento de seguir buscando representación, hasta no alcanzar la independencia, en Madrid, «zoco moruno», en el que había «más granujas por metro cuadrado que en ningún otro sitio de Europa» ${ }^{166}$.

Ibarretxe no mejoró los argumentos de su director en política al condenar la abstención. Esta era una barbaridad, porque debilitaba al nacionalismo vasco, que, por el contrario, debía «defender con energía su proyecto en todos los lugares». Quienes de verdad querían la abstención, según el lehendakari, eran Mayor Oreja y el Partido Popular ${ }^{167}$.

163 El Correo, 26-2-00 (26). La idea de que la abstención significaba ponerse de rodillas ante ETA aparece en Gara, 9-3-00 (16).

164 El Correo, 29-2-00 (18).

165 Ver El Correo, 28-2-00 (23), y Gara, 28-2-00 (13).

166 El Correo, 1-3-00 (19). Lo mismo en Gara, 1-3-00 (18). Críticas a la abstención se encuentran, también, en 5-3-00 (24).

167 El Correo, 5-3-00 (24). 
Muchos abertzales no entendían ni por qué se había roto la tregua ni por qué no se presentaba a las elecciones EH. «No votar es perder — dijo Ibarretxe-; es inhibirse» ${ }^{168}$.

Una valoración parecida de la abstención la hizo Anasagasti. Preguntado sobre si la abstención favorecía al PNV, respondió: «Me hubiera gustado la presencia de EH. Es más, jojalá nos hubiéramos presentado todos con un planteamiento de defensa de cosas muy concretas! Pero para esto era condición sine qua non la desaparición de ETA. Favor nos harían las gentes de HB si nos votaran, pero forman un grupo muy disciplinado y no les veo por la labor de darnos su apoyo» ${ }^{169}$. La razón de no concurrir a las elecciones estaba, según el candidato del PNV, en el previsible descenso de votos de las candidaturas de EH por culpa de los atentados de ETA $^{170}$. Esta misma interpretación la hizo Arzalluz tanto al comenzar como al finalizar la campaña. Según ésta, EH había optado por la abstención, porque sabía que ETA iba a volver matar y no quería perder los 80.000 votos, que ganó con la declaración de la tregua ${ }^{171}$. Con anteridad, Anasagasti había animado a votar a todos los nacionalistas, aunque fuesen radicales, ya que «la abstención logrará que Mayor Oreja gane esta batalla y eso sería terrible porque es el ministro de la guerra, el único que no quiere la paz y eso no se puede permitir» ${ }^{172}$.

Otras cuestiones relacionadas con EH se referían a la reacción del público nacionalista ante el vídeo electoral del PNV. Así como la aparición de los líderes nacionalistas fue recibida con aplausos y vítores, $\mathrm{y}$ la del PP con gritos de ;fuera!, ;fuera!, la aparición en el mismo de líderes de EH fue recibida con silencio ${ }^{173}$. Esta actitud silenciosa, explicada probablemente por la ausencia de opinión de los dirigentes peneuvistas presentes en el acto, contrastaba con la que manifestó el lehendakari, pocos días más tarde, al sentirse profundamente defraudado por sus antiguos socios parlamentarios. Según ésta, el pacto de legislatura se había firmado de buena fe, con la idea de que era el camino de

168 El Correo, 6-3-00 (18). En El Correo, 7-3-00 (21), se repiten estas consideraciones sobre la abstención, añadiendo que el PSOE es también beneficiario de la misma.

169 El Correo, 7-3-00 (20). Arzalluz, por el contrario, esperaba que buena parte de esos sufragios fuesen a las arcas del PNV (El Mundo, 28-2-00 (8)).

170 Ver El Correo, 7-3-00 (21).

171 Ver El Correo, 28-2-00 (23) y 10-3-00 (22); El Mundo, 28-2-00 (8), y El País, 28-2-00 (19).

172 Deia, 27-2-00 (25). Otros lugares de la campaña, donde se rechazó la abstención en Gara, 5-3-00 (6); Deia, 5-3-00 (4); El Mundo, 5-3-00 (10); Deia, 7-3-00 (4 y 5); El País, 9-3-00 (24); Gara, 9-3-00 (16).

173 Ver El Correo, 28-2-00 (23). 
la paz. Un abismo separaba ahora a ambas agrupaciones políticas. Aunque la responsabilidad única era de ETA, Ibarretxe afirmaba que no se podía hacer reflexiones en común, si no se decía que se respetaba la vida. En un ambiente de violencia era imposible debatir cuestiones políticas ${ }^{174}$.

No obstante el abismo de separación entre ambas agrupaciones, Ibarretxe destacaba que muchos abertzales de EH apostaban por la política y no por la violencia. Eran los que, juntamente con el Gobierno Vasco, no entendían por qué ETA había roto la tregua y había vuelto a matar ${ }^{175}$. Eran los que votarían en las elecciones, según Anasagasti, porque no estaban de acuerdo con la violencia ${ }^{176}$.

A cargo de Arzalluz quedó recuperar el orgullo del PNV ante la petición de Otegi de que definiera su postura política: o abertzale o españolista. «Este quién es - manifestó- para decirle al PNV que tiene que ir con el abertzale, si el abertzale es el PNV? ¿Ellos qué son? Unos radicales que creyeron que nosotros íbamos por un camino equivocado porque somos gentes de paz» ${ }^{177}$.

Las diferencias y semejanzas del PNV con HB las describió pausadamente Anasagasti en una entrevista, en la que respondió a las acusaciones de que el Partido Nacionalista Vasco unía paz con construcción nacional y de que estaba en la red soberanista de HB. La respuesta, que consideraba injustas las acusaciones, confirmaba la postura peneuvista ante EH en términos, que repetían uno de los disparates políticos y morales más utilizados por el nacionalismo, el de la posibilidad de separar legítimamente el fin de los medios utilizados: «...El Partido Nacionalista Vasco tiene más de 100 años de historia, está antes que nadie. La relación con EH es complicada, porque nosostros seguimos condenando sin ambigüedades la violencia y la «kale borroka» y ellos siempre hacen distingos. No obstante, nos oponemos a su exclusión política y social. Hay que mirar si la actual HB tiene algo que ver con la de hace dos años. La de ahora ha apostado por vías políticas. Es difícil librarse del mundo en el que se encuentran, pero al final ganarán la bata1la. En cualquier caso, en el PNV basamos la estrategia en el voto, el convencimiento y la palabra, no admitimos ni que ETA ni HB impongan sus modelos. Podremos coincidir en los fines, pero no en los mo-

174 Ver El Correo, 3-3-00 (20). Semejante información en Deia, 3-3-00 (4). La desilusión de Ibarretxe aparece también en Gara, 3-3-00 (22); El Mundo, 5-3-00 (10).

175 Ver El Correo, 7-3-00 (21).

176 Ver El Correo, 9-3-00 (24).

177 El Correo, 6-3-00 (18). 
dos ni en los tiempos» ${ }^{178}$. Estas manifestaciones, que en lo esencial manifestaban la postura oficial del PNV ante EH, concordaban con la petición de «arrojo», que el mismo candidato hacía al Partido Popular y Euskal Herritarrok ${ }^{179}$.

Ahora bien, el comunicado de ETA, ya al final de la campaña, sobre el asesinato de Buesa, que mereció el respaldo de EH, pondría de manifiesto cierta disparidad entre el criterio de Anasagasti y la línea oficial del partido, que muy pronto sería solventada. "Que EH avale ese comunicado y la muerte (sic) y los insultos hacia Buesa es absolutamente imcomprensible», manifestó Anasagasti. Con ello HB había demostrado que seguía sometida a una ETA, cuyos esquemas eran de hacía cuarenta años. Una conclusión se imponía: «...cambiar de estrategia entre todos», ya que EH había adoptado una postura radicalmente contraria a la que había seguido hasta el comunicado de ETA. «Cuando el lehendakari pacta con EH, añade, pacta la ausencia definitiva de la violencia, y en este momento está hablando la violencia. Es un cambio cualitativo total». El PNV no estaba dispuesto a seguir a los iluminados de ETA y su pretensión de dirigir la política vasca. Una vez celebradas las elecciones, Anasagasti pensaba que «todo se tendrá que replantear» ${ }^{180}$.

Hechas estas manifestaciones a la Cope, Anasagasti se vio obligado a explicar el significado de las mismas. Estas no habían querido ser el anuncio de una ruptura con $\mathrm{EH}$, lo cual habría ido en contra de la línea oficial del partido, sino el «llamamiento a todos los partidos para reflexionar y superar esta situación». La necesidad de buscar nuevos apoyos parlamentarios (y aquí se decía que el pacto con EH estaba roto) estaría sujeta también «a los planteamientos de otros partidos políticos, y yo creo que aquí se pueden dar cambios múltiples, no sólo en el PNV, sino también en otros partidos» ${ }^{181}$.

Por lo que respecta a ETA, los testimonios manifestaban el repudio y la negación de cualquier acuerdo pasado o presente con ETA ${ }^{182}$. Egi-

178 El Correo, 7-3-00 (20). Gara, 5-3-00 (6), recoge también diferencias y semejanzas. Defensa de una estrategia favorable a la integración de EH en instituciones en El País, 6-3-00 (26); Gara, 7-3-00 (17): «No renunciaremos a la colaboración entre abertzales» (Egibar).

179 Ver El Correo, 10-3-00 (22).

180 El Correo, 10-3-00 (27).

181 Ibídem.

182 Ver El Correo, 29-2-00 (18) y 1-3-00 (19), donde es Arzalluz el que afirma: «No tenemos ningún acuerdo con ETA ni lo hemos tenido nunca». En Gara, 7-3-00 (17), Egibar habla de relación epistolar con ETA, pero sin mediar acuerdo. Sobre el rechazo de ETA ver, además de lugares citados en texto, Deia, 8-3-00 (4 y 12); El País, 9-3-00 (24 y 25). 
bar dijo, incluso, que «desgraciadamente no hemos firmado ningún acuerdo con ETA»183.

La argumentación utilizada para condenarla era variada. Una línea de argumentación destacaba el provecho político, que el PP sacaba de la existencia de ETA. Era ella la que había encumbrado al ministro del Interior, que de no ser por ella «sólo sería un ingeniero agrónomo». No obstante, Anasagasti, a quien se deben estas últimas palabras, aseguraba que la desgracia del país no era Mayor Oreja, sino ETA ${ }^{184}$.

Otro argumento destacaba la inutilidad de la violencia para liberar al País Vasco y la deslegitimación de las ideas nacionalistas que provocaba. Así, por ejemplo, Arzalluz manifestó que «crcer que la violencia es el medio para liberar este país es estar haciendo el ridículo» ${ }^{185}$.

La inutilidad de la violencia se manifestaba, también, en el fracaso de la misma para hacer cambiar de postura al PNV o al mismo Gobierno central. Calificada ETA como residuo del franquismo, Anasagasti manifestó como voluntad política de su partido la decisión de eliminar semejante legado de Franco ${ }^{186}$.

La condena de la violencia en cuanto negación de la vida aparece con claridad en el texto del EBB, que más arriba se ha mencionado, en el que se decía que ETA con sus asesinatos atentaba contra lo primero y más importante, el derecho a la vida, aunque también atentaba contra el diálogo, contra la Declaración de Lizarra, contra la política nacionalista seguida desde Lizarra, contra la construcción democrática y la construcción nacional ${ }^{187}$. Posteriores declaraciones, v.g. las palabras de Ibarretxe, que siguieron al atentado de ETA contra una patrulla de la Guardia Civil en San Sebastián, unían peligrosamente el respeto a la vida y el respeto a la sociedad vasca. «Este no es el camino - dijo en referencia al atentado- - Hay que hablar, dialogar; pero no se puede matar. Tenemos que respetar la vida, tenemos que oír y respetar a la sociedad vasca» ${ }^{188}$.

El mismo atentado hizo que el alcalde de Bilbao, Iñaki Azkuna, destacara lo que significaba en cuanto ataque a «la confrontación libre y pacífica de ideas, el máximo exponente de la democracia». De ahí

183 Gara, 28-2-00 (13).

184 El Correo, 2-3-00 (20).

185 El Correo, 4-3-00 (24), y El País, 9-3-00 (24).

186 Ver El Correo, 8-3-00 (20), y Deia, 8-3-00 (4).

187 Ver Deia, 25-2-00 (5).

188 El Correo, 8-3-00 (24). Los heridos por el ataque de ETA con un coche bomba contra una patrulla de la Guardia Civil en Donosti fueron ocho (ver El Mundo, Deia y Gara del 7-3-00 (1)). 
que, además de condenarlo, pidiese a los bilbaínos su confianza en la democracia y la participación en las elecciones para respaldar las vías democráticas ${ }^{189}$.

Arzalluz acusó a ETA de mentir por afirmar en su comunicado que tanto el PNV como EA no habían respondido de manera directa y concreta a la propuesta que les hizo llegar en julio de 1999. Sólo habrían respondido con descalificaciones carentes de fundamento, lo que supuso la razón del abandono de la tregua. ETA apoyaba la abstención y criticaba a los dos partidos nacionalistas por presentarse a las elecciones, pero el presidente del PNV trataba de salvar la independencia de su partido con la afirmación de que «van dados», si quieren imponer los etarras sus proyectos al PNV ${ }^{190}$.

Fue Egibar, en cuanto portavoz del PNV, el que expresamente contestó al comunicado de ETA en una rueda de prensa convocada al efecto. El comunicado atacaba de manera frontal y directa el esquema de solución del «conflicto político» que el Pacto de Lizarra proponía, Pacto que el PNV no pensaba abandonar, a pesar de que no se habían cumplido los dos objetivos para los cuales se creó, el fin de la violencia y la incorporación de HB a la vida democrática. El Partido Nacionalista Vasco seguía pensando que la estrategia iniciada era válida y que, por consiguiente, la sociedad no tenía «que rebajar ni relajar su trabajo y tensión en pos de un proceso político y de paz». Egibar destacó, además, que la intervención de ETA desplazaba «a EH de la acción política y democrática autónoma» y demostraba un desprecio absoluto a los derechos humanos y al sentir mayoritario de la sociedad vasca. Su irrupción en la campaña había sido antidemocrática «no sólo con acciones, que es lo más grave, sino con proclamas abstencionistas». El PNV, seguía el portavoz, observaba con preocupación el inaceptable análisis «impositivo» de ETA, en el que se inventaba una realidad, faltaba realismo, faltaba humildad y sobraba soberbia, todo lo cual llevaba a ETA a «la interpretación única de la realidad». ETA debía ser consciente y responsable de decisiones y acciones, que, tras la ilusión producida por la tregua, cortaban en seco la posibilidad de buscar soluciones políticas y democráticas. Tal actitud de ETA debía «tener respuesta en las urnas». Egibar rechazó la acusación de cobardía dirigida contra el Partido Nacionalista Vasco e Ibarretxe añadiendo que si había algo que descalificaba al presunto valiente era «la exhibición y uso de pistolas y bombas». A diferencia de ETA, se concluía, el PNV sólo utilizaba como

189 El Correo, 8-3-00 (24).

190 Ver El Correo, 9-3-00 (24). 
«armas sus proyectos, la persuasión y el voto. ETA no puede decir lo mismo» ${ }^{191}$.

Según Anasagasti, ETA había desvirtuado la campaña con sus atentados. No se podía tolerar que, así como antes Franco no dejaba votar, ahora fuese ETA la que no permitía hacerlo ${ }^{192}$.

Una nota de la ejecutiva del PNV, posterior a la intervención de su portavoz, volvía a repetir prácticamente lo dicho por éste: el rechazo de la tutela de una organización armada; la calificación de los atentados de absolutamente rechazables y condenables; la interpretación de que ETA y sus acciones eran «el gran obstáculo para la normalización política y social del país» y la acusación de haber frustrado la ilusión y la esperanza. La nota, además, añadía que el PNV había contestado a la propuesta de ETA de celebrar unas elecciones para un «parlamento nacional» con un claro «no». La conclusión establecía: «ETA sobra y estorba. Su única aportación a esta sociedad será su desaparición» ${ }^{193}$.

La repetición en el acto final de la campaña, con intervenciones de Arzalluz e Ibarretxe, de los principales argumentos utilizados por el PNV contra ETA, demostraba la utilización partidista y electoralista de la violencia. Para el PNV la violencia daba la razón al «enemigo», fundamentalmente al PP, y era un argumento más, un cañonazo más, contra el PNV. Parecía decirse que el PNV era la principal víctima de la violencia y de la estrategia de ETA. Arzalluz insitió en el uso de la

191 El Correo, 9-3-00 (30). Ver, también, El País, 9-2-00 (24) y (4), donde González de Txabarri dice: «En realidad se trata de un pulso por el poder que ha lanzado ETA al PNV desde su propia debilidad... (...) ...ETA está señalando con el dedo a los militantes del PNV... (...) ...nosotros no los aireamos (los intentos de ETA contra el PNV)»; Gara, 9-3-00 (14) y (16), donde se lee: «En este comunicado se plantea una estrategia poli-mili. Hay alguien que ha cogido algún libro de anticuario al redactar ese comentario. A mí me ha rejuvenecido. Esa es la ETA de antes de la Mesa de Alsasua. Esos términos... es irnos veintitantos años atrás. ¿Para qué hemos hecho este trabajo de los últimos dos años? El PNV se ha exigido a sí mismo un esfuerzo titánico en este proceso. Dentro de casa ha habido que hacer un esfuerzo sobrehumano en muchas ocasiones, para enfocar y dirigir la acción política del colectivo social y político más importante y más amplio de este país; para orientar decisivamente un proceso político, que es ilusionante y que tiene la posibilidad de dar un salto cualitativo de cara al futuro, una posibilidad de cerrar un proceso histórico lamentable. Y estos días, con los atentados y con el comunicado de ETA, nos llevan en el túnel del tiempo más de veinte años atrás. Por eso estamos pidiendo insumisión a ETA. Esta es una campaña completamente atípica, donde tenemos la oportunidad de poner a ETA en su sitio y mandarla electoralmente al baúl de la historia y, también democráticamente, colocar a Mayor Oreja en la minoría donde le hemos puesto en los últimos veinte años»; El Mundo, 9-3-00 (8); Deia, 9-3-00 (22).

192 Ver El Correo, 10-3-00 (22).

193 El Correo, 10-3-00 (27). También, El País, 10-3-00 (23); Deia, 10-3-00 (21); Gara, 10-3-00 (18). 
mentira por parte de ETA contra el PNV en la línea de lo que había dicho la nota del EBB y, también, en que estaba «dando la razón al enemigo, y digo enemigo y no adversario, porque nos quieren liquidar», afirmación belicista, que no se corresponde de ninguna manera con la idea de Anasagasti de que Arzalluz era «factor de moderación dentro del PNV»194.

Ibarretxe, por su parte, presentó a su partido en el centro de los ataques de todos los demás, extremando el argumento, se puede añadir, del «enemigo». Este ya no sería particular e individual, sino casi universal. Españoles y abertzales radicales, según esto, habrían hecho una campaña contra el PNV. Era una forma, la forma negativa, de llamar a toda la militancia, electorado y simpatizantes a cerrar filas en torno al partido y su dirección. Ibarretxe, que pedía respeto a la vida, para poder discutir proyectos políticos, interpretó así las elecciones: «todos los cañones han tirado contra el PNV: ETA matando, EH con la abstención, y el PSOE y el PP tratando de mezclar nacionalismo y violencia e intentando generar odio en una sociedad que necesita ilusión» 195 .

Todo este tratamiento de la violencia no se correspondía con la rotundidad, con la que parece que se dijo en otras ocasiones que «ninguna idea, por hermosa que sea, vale la vida de un ser humano» o que lo primero era el respeto a la vida y «después (vendría) todo lo demás» ${ }^{196}$.

\section{Partido Socialista de Euskadi-PSOE}

A diferencia de lo que ocurrió con el Partido Popular, el Partido Socialista fue muy poco tenido en cuenta en el debate electoral. Como más arriba se ha indicado, sólo el 8,23\% de la atención a partidos estuvo dirigida al PSE-PSOE, es decir, el 5,78\% de la campaña.

Los actos, que siguieron al asesinato de Buesa, fueron el instrumento más utilizado por el PNV en sus críticas antisocialistas, que, en su mayor parte, coincidían con las hechas al Partido Popular. La responsabilidad, según esto, de la imagen de división social, crispación y polémica causadas en la manifestación era fundamentalmente de los socialistas, a los que de manera específica se les atribuyó una actitud de deslealtad con las instituciones democráticas por haberse manifes-

194 El País, 9-3-00 (25).

195 El Correo, 11-3-00 (18). Ver, también, sobre ETA: Deia, 8-3-00 (4 y 12); El País, 9-3-00 (24 y 25).

196 Gara, 3-3-00 (22), y Deia, 10-3-00 (4), palabras de Iñaki Anasagasti. 
tado con pancarta diferente a la que se presentó en la convocatoria oficial del lehendakari. Ante un acto institucional, unitario e integrador, populares y socialistas habían actuado de mala fe introduciendo elementos distorsionadores. El portavoz del Gobierno Vasco, Imaz, comparó la actitud de socialistas y populares con la mantenida por EH en la manifestación del 15 de enero, en la que se manifestó con lema distinto del que llevaron los demás integrantes del Pacto de Lizarra. La crítica de Imaz calificó de sin sentido el discurso del socialista Javier Rojo una hora más tarde de que lo hubiese hecho el lehendakari, ya que la manifestación no tenía más que un único convocante. Por otra parte, si bien el discurso de Ibarretxe había sido, según él, «integrador, por la paz, contra ETA y por la pluralidad», el de Rojo, por el contrario, contenía «elementos partidistas» 197 .

No es cuestión de repetir las acusaciones contra los socialistas, dichas también contra los populares, que se recogen más arriba. Basta recordar cómo comentarios posteriores interpretaron la conducta socialista y popular como hecha por profesionales y como parte de una planificación orientada a fracturar y crispar a la sociedad vasca, de la que habrían dejado constancia determinadas supuestas palabras de la socialista Rosa Díez. En Vitoria se habría tratado de humillar al nacionalismo y de atribuirle responsabilidades ${ }^{198}$.

Si bien el resto de las acusaciones contra los socialistas fueron pocas, tuvieron, sin embargo, gran calado. Además de considerarlos «monaguillos» del PP, se les hizo responsables de que la parte social del Estatuto no se hubiese desarrollado, mientras Almunia fue ministro de Administraciones Públicas. Por otra parte, ante el distinto tratamiento de la violencia, la vía policial de los populares o el diálogo de los nacionalistas del PNV, los socialistas mirarían para otro lado, según Arzalluz. Pero lo más grave y gratuito lo dijo Ibarretxe, al afirmar que los socialistas, junto con los populares, mezclaban nacionalismo y violencia e intentaban crear odio en la sociedad vasca ${ }^{199}$.

Sin embargo, alguna expectativa o intención electoral o pretensión de desprestigiar a los populares había en relación a los socialistas, cuando Arzalluz defendía consensuar fórmulas de paz con el PSOE,

197 El Correo, 28-2-00 (15). Imaz no explicó el por qué de los gritos nacionalistas más a favor del lehendakari que en contra de ETA.

198 Ver El Correo, 29-2-00 (18).

199 Ver El Correo, 5-3-00 (24); 7-3-00 (20); 11-3-00 (18). En Deia, 3-3-00 (4), Ibarretxe aparece diciendo con anterioridad: «No podemos permitir que nadie mezcle nuestras ideas con la violencia o que somos conniventes con la violencia, porque nosotros somos nacionalistas, pero demócratas». 
aunque no ganasen las elecciones, ya que, en cualquier caso, con Gobierno socialista o sin él, el PSOE se iba a despegar «de esa situación» ${ }^{200}$. En este sentido Arzalluz declaró: «Estamos deseando que pasen las elecciones porque estoy seguro de que los socialistas volverán otra vez a un camino mucho más lógico, para encontrar fórmulas conjuntas de ir caminando hacia la paz, sin el PP si hace falta» ${ }^{201}$. Apoyaba su seguridad en el supuesto reconocimiento de Almunia de la validez del plan de Ardanza como punto de partida.

Semejantes observaciones pueden hacerse a las declaraciones de Anasagasti por los «continuos guiños» del PNV al PSOE: «Hay que recordar que en el PSOE Felipe González acabó su período presidencial teniendo un mediador internacional: Pérez Esquivel. Le veo a Almunia más propicio a hacer movimientos, a tomar temperaturas, a hacer cosas porque capta mejor que el PP que el tema de la violencia no se va a resolver si no hay discusión, negociación y diálogo político. Pero tampoco nos engañemos, porque el PSOE no es la madre Teresa de Calcuta...» ${ }^{202}$. El mismo Anasagasti ya había manifestado que «si el Partido Socialista ganase, sería mucho mejor para todos» ${ }^{203}$.

\section{Eusko Alkartasuna}

No existió este partido electoralmente hablando más que para recordar a los votantes que no se podía perder ni un sólo voto nacionalista, ya que había que evitar a toda costa que el Partido Popular sacase mayoría absoluta. Como EA no tenía posibilidades de sacar un escaño por Bizkaia, según Anasagasti, sus 40.000 votos irían a la basura. El argumento se utilizó al final de la campaña, lo que sugiere que el silencio anterior obedecía a las necesidades argumentales del PNV de presentar al Partido Popular empeñado en una estrategia general antinacionalista,

\footnotetext{
200 Ver El Correo, 29-2-00 (18). También Gara, 1-3-00 (18).

201 El Mundo, 29-2-00 (9).

202 El Correo, 7-3-00 (20).
}

203 El País, 6-3-00 (28). En el programa El Farol, de Radio Bilbao, Anasagasti y Benegas mostraron más puntos de acuerdo que diferencias; la ausencia de Mayor Oreja le permitió calificarla como «desprecio olímpico» al problema vasco (El País, 7-3-00 (1)); Deia, 10-3-00 (12) recoge su preferencia por Almunia en la Moncloa. Como el sondeo del CIS no apoyaba tales preferencias, Anasagasti comentó de manera muy propia de su presidente de partido que «tenemos una información de Madrid que nos dice que la encuesta que ha hecho pública el CIS y que da cinco puntos de diferencia al PP está inflada y que hay un empate técnico entre el partido de Aznar y el Partido Socialista. El PP no tiene motivos para el triunfalismo; tengo información de que están muy nerviosos, porque el efecto IU-PSOE les puede afectar muy directamente» (El Correo, 4-3-00 (25)). 
que para ser más creíble obligaría a (o más bien recomendaría) aparentar la unidad del nacionalismo más allá de la realidad ${ }^{204}$.

Lo mismo argumentó J. Erkoreka: «Yo no voy a decir nada en contra de EA aunque ellos nos critiquen. Pero lo que es cierto es que para que Eusko Alkartasuna consiga un diputado en Bizkaia tendrían que conseguir doblar el número de votos que poseen en la actualidad, lo que es bastante difícil. En cambio, al Partido Nacionalista Vasco le bastaría con la mitad de esos votos para lograr el cuarto diputado en Bizkaia, por lo que en estos momentos votar a EA en Bizkaia es perder un voto» ${ }^{205}$. De todos modos, Deia acusó a Sabin Arana de hacer publicidad electoral «con sello y dinero de la Diputación de Bizkaia. ¡Qué feo!» ${ }^{206}$.

\section{LA CAMPAÑA DE EUSKO ALKARTASUNA}

\section{Datos básicos}

La información periodística de la campaña de EA fue cuantitativamente bastante más reducida que la del PNV. Sólo alcanzó las 724 unidades, es decir, el $40 \%$ de la del PNV. Con ello se repetía el mismo fenómeno de otras campañas. La imagen del partido ocupó el 49,44\%, mientras que la crítica a los partidos alcanzó el 50,55\% restante. En este caso la estrategia electoral negativa quedó prácticamente al mismo nivel que la presentación del proyecto político, lo que constrastaba radicalmente con lo ocurrido en la campaña del PNV.

La imagen se elaboró a base de ideología nacionalista con sus clásicos contenidos de autodeterminación, independecia, nuevo marco jurídico-político de convivencia, autonomía y la cuestión de Navarra (o las relaciones entre Euskadi y Navarra). Esto ocupó el 24,44\% de la campaña, una cota muy elevada si se compara con el PNV, lo que representaba el $49,44 \%$ de la imagen de partido. La estrategia de la paz o lucha antiterrorista $(9,66 \%$ y $19,55 \%$, respectivamente), la justificación de la petición del voto $(4,69 \%$ y $9,49 \%)$ y otras cuestiones (paro, empleo, mujer y traslado del «Gernika») $(10,63 \%$ y $21,50 \%)$ completaron la presentación electoral de EA. A todo ello hay que añadir la información del contenido del programa, hecha directamente por la prensa, $\mathrm{y}$

\footnotetext{
204 Ver El Correo, 10-3-00 (22).

205 Deia, 7-3-00 (1)

206 Deia, 7-3-00 (11).
} 
que alcanzó una extensión prácticamente idéntica a la dedicada con el mismo fin al programa del PNV.

El binomio EH-ETA ocupó la preferencia crítica de los políticos de EA alcanzando el $19,06 \%$ y $37,70 \%$ respectivamente. La mayor parte de esta atención recayó sobre ETA con el $15,74 \%$ y $31,14 \%$. A poca distancia se situó el PP con un $17,67 \%$ del total de la campaña y un $34,97 \%$ de la crítica. Según esto, si se separa a EH de ETA, también en la campaña de Eusko Alkartasuna, los populares ocuparon las preferencias de los nacionalistas. El tercer lugar lo ocupó el PNV con una atención del $8,97 \%$ y $17,75 \%$. El último lugar fue para el Partido Socialista con un $4,83 \%$ y un $9,56 \%$. Izquierda Unida no fue tenida en cuenta.

La prensa sólo recogió la participación de 7 políticos de EA: Begoña Errazti, 8 intervenciones; S. Arana, 6; B. Lasagabaster, 5; C. Garaikoetxea, 5; M. Mintegi, 2; G. Knörr, 1 y S. Intxaurraga, 1.

\section{El desarrollo de la campaña}

\section{A) La imagen del partido o proyecto político}

1. El contenido nacionalista

La coherencia discursiva, que, con otro sentido, EA se atribuía como signo distintivo ante los demás nacionalismos ${ }^{207}$, no se aprecia en la presentación de sus tesis nacionalistas. Estas, más bien, parecían recetas propagandísticas que afirmaciones integradas en un discurso lógico. Tal vez, remitían al oyente la estructuración, ad libitum, de sus máximas políticas, o, tal vez, la reducida información periodística dificultaba ver objetivamente el entramado de sus proposiciones. La cosa resulta llamativa, porque las campañas anteriores de EA fueron, al margen de sus resultados, las más estructuradas y las mejor trabadas.

Frente a una cantidad insignificante en el caso del PNV, los temas nacionalistas ocuparon casi una cuarta parte de la campaña de EA y la mitad de su proyecto político. Su definición ideológica independentista, formar un Estado dentro de Europa, y socialdemócrata ( «la socialdemocracia vasca, impregnada de ecología») fue desarrollada un tanto en su dimensión nacionalista ${ }^{208}$, dentro de un programa cuyos

207 Ver El Correo, 3-3-00 (20) y 6-3-00 (20). La coherencia se refiere a la continuidad en rechazar la violencia, defender el independentismo y mantener lo mismo en todos los foros.

208 Ver El Correo, 5-3-00 (26) y 6-3-00 (20). 
ejes fundamentales no eran tan ambiciosos, políticamente hablando, como los últimos fines del partido: «Autogobierno, defensa del Concierto Económico, un nuevo marco jurídico y, sobre todo, la pacificación» ${ }^{209}$. El Consejero de Justicia, Intxaurraga, recordaría en la campaña que EA no sólo era nacionalista, sino independentista y socialdemócrata desde su origen ${ }^{210}$.

El tema político preferido fue el de la autodeterminación. La propuesta exigía dar la palabra a la ciudadanía vasca. España y el País Vasco debían resolver la «articulación democrática dando la palabra a los hombres y mujeres de nuestro país». La profundización democrática constituía la base para sustentar el nuevo marco político. No había que inventar ningún procedimiento, porque, según palabras de Sabin Arana, los modelos de Irlanda y Quebec ya habían establecido el método a seguir ${ }^{211}$.

209 El Correo, 11-3-00 (22).

210 Ver Deia, 29-2-00 (5). Sobre la Dieta vasconavarra y la independencia, Gara, 28-2-00 (15): «Consideramos que el debate sobre el marco jurídico político tiene que desarrollarse aquí. No obstante, cada momento histórico tiene su dinámica, su estatus jurídico político, y creemos que es el momento de abordar ese nuevo marco y de hacerlo entre todos. La propuesta de EA combina, por una parte, la realidad y, por otra, nuestros objetivos finales, que se resumen en la independencia en Europa. Dentro de esa realidad, combina las dos cuestiones claves: soberanía y territorialidad. Se trata de esbozar lo que es factible. Nosotros no solemos escondernos en la ambigüedad, ni decimos una cosa aquí y otra allá, ni en función de las circunstancias peores o mejores. Nos pareció que teníamos que presentar el esbozo de cuál puede ser nuestro planteamiento, aunque somos conscientes de que esto requiere un debate en profundidad, de que esto requiere ponerse de acuerdo entre todos, pero nuestra propuesta sería en esta dirección. Nos pareció leal con todo el mundo hacer llegar esas líneas generales». Sobre la compatibilidad del nuevo marco político con el desarrollo del Estatuto, ibídem: «No está reñido lo uno con lo otro, no es incompatible. Reivindicar lo que falta, la lealtad a aquel espíritu del Estatuto, no es incompatible con ese nuevo impulso porque, en la medida en que tengamos un cierto acervo, cuantas más cuestiones de autogobierno tengamos conseguidas, eso que tenemos por delante. Cuanto más tengamos, más fácil nos será adquirir ese nuevo marco jurídico político. Además, defendimos en su momento el Estatuto, pero siempre hemos dicho, y lo dice el Estatuto, negociamos en su momento sin perjuicio de los derechos históricos que tiene este país». Ambas citas son declaraciones de Begoña Lasagabaster, para quien el autogobierno consistía en «obtener soluciones propias a problemas propios». Sobre la independencia ver: Deia, 4-3-00 (10); Gara, 6-3-00 (12), donde Garaikoetxea dice: «Vamos a Madrid a decir lo mismo que decimos aquí: que no somos españoles ni franceses y que Euskal Herria es nuestra única patria»; Deia, 10-3-00 (5); Gara, 10-3-00 (23).

211 Ver El Correo, 27-2-00 (40). Sobre la autodeterminación, Begoña Lasagabaster manifestó en Gara, 28-2-00 (15): «Hemos defendido el derecho de autodeterminación en multitud de ocasiones en la tribuna de la Cámara de Madrid. Fue una de las cuestiones que planteamos en el debate de investidura de Aznar. Está en todos los programas, estatutos y ponencias políticas de EA. No lo decimos ahora, incluso hemos llegado a pactar ese com- 
Los intereses que la presidenta del partido prometía defender en Madrid eran, precisamente, un cambio jurídico-político y la autodeterminación ${ }^{212}$. Esta, la palabra y la decisión del pueblo, era la que ETA negaba al utilizar «a su antojo la vida ajena» ${ }^{213}$.

El proceso desde la autonomía hasta la independencia fue explicado o confundido en estos términos: «...Propugnamos ir hacia un nuevo marco, pero el asunto es progresivo y en el ínterin exigimos que se cumplan las deudas. ¿En cuánto tiempo se debe articular otro marco? En uno, dos o cinco años se puede proponer un referéndum y con lo que salga, tirar otro período hasta que las autoridades noten un cambio» ${ }^{214}$. A estas palabras, que más bien parece que hay que interpretarlas en broma, seguía la disparatada afirmación de que, aunque no estaba decidido, la mayoría exigible en el referéndum era la mayoría simple.

No se sabe con exactitud si el referéndum de la autodeterminación era un instrumento a ejercitar únicamente ante el dilema de la independencia o la continuidad en la unión política, o si también debía jugar alguna función ante objetivos más modestos. El caso es que, de momento, la aspiración del partido era articular un nuevo marco de convivencia, que superara el Estatuto y se integrara con normalidad en la Unión Europea. Así lo manifestó el cabeza de lista por Alava ${ }^{215}$. La presidenta del partido manifestó más sencillamente que se pensaba defender en Madrid un cambio jurídico-político ${ }^{216}$. Estos cambios debían

promiso recientemente con ERC, en el acuerdo de Iruñea. Para la próxima legislatura hay dos cuestiones claras que vamos a plantear: la autodeterminación, el ejercicio de este pueblo a decidir lo que quiera, y la pacificación. No apoyaremos a ningún gobierno que no vaya en esa dirección. Lo decimos antes del 12-M, para que todo el mundo tenga clara cuál va ser nuestra actuación política». Ver, también, Gara, 5-3-00 (6); Gara, 6-3-00 (12); Gara, 11-3-00 (18): «No vamos a Madrid a mendigar, sino a exigir la autodeterminación» (Errazti).

212 Ver El Correo, 6-3-00 (18). En El Correo, 11-3-00 (22), B. Errazti dice: «No vamos a Madrid a mendigar, vamos a exigir la autodeterminación y todo lo que haga falta para Euskal Herria».

213 El Correo, 8-3-00 (24).

214 El Correo, 6-3-00 (20).

215 Ver El Correo, 4-3-00 (24). En El Correo, 3-3-00 (20), B. Lasagabaster destacó la necesidad de una mayor participación de las comunidades autónomas en la Unión Europea ante la mala actuación del Gobierno central.

216 Ver El Correo, 6-3-00 (18). También Sabin Intxaurraga defendió el nuevo marco jurídico-político, que debería servir para integrar en un solo Parlamento a los tres territorios de Euskal Herria (Deia, 29-2-00 (5)). Así explicó Mikel Irujo la idea de una dieta vasconavarra: «Para nosotros la idea de crear una dieta no representa un fin en sí mismo. Nuestro ideal, sin querer imponérselo a nadie, es una Euskal Herria unificada y confederada dentro de la UE, pero no se puede negar la realidad que vivimos, la de un pueblo 
afectar, también, al modelo de incorporación de Navarra a la Comunidad Autónoma del País Vasco, que se había quedado anticuado. El nuevo modelo, más democrático, se basaba en una dieta paritaria Euskadi-Navarra, que superaría la pretensión de que el territorio foral, alejado de Euskadi no por el nacionalismo, sino por la violencia, se incorporase a la Comunidad Autónoma del País Vasco ${ }^{217}$. Todo ello parecía sugerir que la profundización democrática y el nuevo marco se intentarían lograr desde la Constitución y el ordenamiento jurídico vigentes.

Obsérvese cómo detrás de estos objetivos y proyectos políticos estaba, como siempre, la creencia en un pasado mítico, del que Begoña Lasagabaster lamentaba que la gente renegase. Según la candidata de $\mathrm{EA}$, parte de los vascos renegaba de su historia (en realidad ignoraba o rechazaba una historia mítica), una historia que mostraba que ni eran mejores ni peores que otros, sino «diferentes». Los vascos actuales querían mantener «sus señas de identidad», porque «somos un pueblo que ha tenido su propio ordenamiento jurídico y sus propias peculiaridades, y las queremos seguir manteniendo». Los nacionalistas de EA pretendían «resolver los problemas de los ciudadanos y tener lazos, puentes y relaciones cordiales con los vecinos españoles, franceses o de otros pueblos de la Unión Europea» ${ }^{218}$.

\section{Contenidos no nacionalistas}

La interpretación del problema de la violencia y de la estrategia para su solución fue expuesta de manera más ordenada y ocupó el primer lugar de las cuestiones no estrictamente nacionalistas. Ya la exposición del programa hecha por la prensa mostraba la voluntad de EA de exigir a ETA que cesase en su lucha armada (sic) y de urgir al Gobierno central la negociación y la aportación de soluciones políticas al contencioso (sic) vasco. La paz requería políticas de acercamiento de los presos, excarcelaciones y resarcimiento moral y económico a las víctimas de la violencia ${ }^{219}$.

vasco dividido entre dos estados fuertes y, además, en el sur, entre dos comunidades autónomas. Y para dar pasos realistas de acercamiento proponemos crear una dieta, un órgano común paritario, con un consejo propio, en el que ambas comunidades aborden el estudio y solución de problemas comunes. No es nada que no esté, incluso, reconocido como derecho en una Constitución que no nos gusta, pero cuya disposición transitoria cuarta regula el mecanismo de unión política de ambas comunidades».

217 Ver El Correo, 6-3-00 (20).

218 Deia, 2-3-00 (10). Esta interpretación se hizo en el caserío de Usarraga en el 300 aniversario del último pleno de las Juntas Particulares de Guipúzcoa.

219 Ver El Correo, 1-3-00 (22). 
El tratamiento de campaña, si bien no se salió básicamente de este esquema, fue más amplio en algunos puntos y justificó la pretensión de que fuera uno de los ejes del planteamiento político de EA.

La persistencia de la violencia no sólo creaba sufrimiento, sino que perjudicaba, sobre todo, al nacionalismo, a las fuerzas nacionalistas y a la construcción nacional. La violencia destrozaba, desorientaba y desmotivaba a los nacionalistas. EA apostaba por buscar una solución dialogada a lo que calificaba de «conflicto vasco» o de «contencioso», ya que, en su opinión, no había más que dos soluciones: o la negociación, propia de los países civilizados, o la vía policial, cuya consecuencia sería el aumento de la ruptura social ${ }^{220}$. Y la negociación significaba «hablar sin ningún tipo de límite». No había otro «remedio ni otra fórmula de convivencia» ${ }^{221}$.

Esta forma de argumentar, que destacaba el aspecto humano y, especialmente, los daños para el propio nacionalismo derivados tanto del uso de la violencia (estrategia de ETA) como de su tratamiento policial (el fantasma de la división social, es decir, el fantasma de las dos comunidades tantas veces negado por los nacionalistas), destacaba la raíz política e histórica del problema en cuanto fundamento de una negociación o diálogo político. Así lo expresó la presidenta del partido al afirmar que el problema de la violencia era "político y de raíz histórica», por lo que su solución no era «a través de la vía policial, sino mediante el diá$\operatorname{logo}$, el entendimiento y el esfuerzo de la conciliación ${ }^{222}$.

Se quería decir, primero, que, si el origen del problema era político, la solución debía ser también política, y, segundo, que, siendo la política esencialmente parlamento, diálogo y negociación, sobraban allí tanto la violencia de ETA como la del Estado, como si no hubiera distinción, hay que añadir, entre una violencia ilegítima y otra legítima. Esta forma simple e interesada de interpretar tanto la historia como la política escondía los supuestos de la imposibilidad de una victoria policial del Estado o de la incoveniencia para el nacionalismo de una tal victoria. Por otra parte, ignoraba, también, que la utilización de la violencia legítima por parte del Estado es parte esencial de la política y era, por tanto, respuesta política. Pero el modo de argumentar nacionalista todavía ocultaba más cosas. Ocultaba que, estando la legitimidad y la razón, al menos, histórica de parte del nacionalismo, según su inter-

220 Ver El Correo, 1-3-00 (19). Ver, también, Deia, 1-3-00 (5); Gara, 1-3-00 (18); Deia, 8-3-00 (5), donde la solidaridad con las víctimas se extiende a las de la Guardia Civil.

221 Deia, 2-3-00 (10).

${ }^{222}$ El Correo, 6-3-00 (12). Ver Gara, 6-3-00 (12); Gara, 7-3-00 (12): diálogo sin límite. 
pretación, la violencia nacionalista era en realidad la legítima ante una violencia del Estado, que no quería reconocer ni la razón, ni el derecho, ni la legitimidad del nacionalismo. Se ocultaba la tesis de que la violencia del Estado era ilegítima y constituía la forma de imposición de una solución no dialogada, es decir, no política. Si la presidenta rechazaba la violencia de ETA, lo hacía por su daño humano, pero, no menos, por su ineficacia, daño y desprestigio del nacionalismo.

Todas estas consideraciones estaban, con alguna nueva aportación, expresa o tácitamente dichas en una intervención de la candidata al Congreso por Guipúzcoa, Begoña Lasagabaster, sobre la pacificación o «normalización». La añadidura de esta candidata completaba la argumentación nacionalista sobre el terrorismo. Según ésta, la paz y la normalización de Euskal Herria pasaban necesariamente por el hecho de que todos se sentaran a la misma mesa sin límites o restricciones. Esto tenía que hacerse, gustase o no gustase a Madrid. EA no estaba dispuesta a apoyar a un Gobierno, que no apostase seriamente por la pacificación. Ahora bien, la pacificación debía construirse sobre el respeto a los derechos humanos. Y era aquí, donde el nacionalismo introducía el eje de su argumentación, al afirmar que la paz «no es fruto únicamente de la tranquilidad en el orden, sino también de justicia o, lo que es lo mismo, del respeto a los derechos individuales, por supuesto, y colectivos» ${ }^{223}$. A partir de aquí, se disponía de la estructura argumental para desligitimar todas las violencias existentes en la sociedad vasca desde la de ETA hasta la del Estado. Un concepto de justicia, que consideraba derechos humanos tanto a los individuales como a los colectivos, y que los situaba al mismo nivel, permitía exigir la desaparición de la violencia en todas sus expresiones, «llámese ETA, GAL, "kale borroka", torturas, dispersión o alejamiento de los presos vascos de su entorno familiar, negación de la expresión de la voluntad a un pueblo» ${ }^{224}$. Una tal justicia servía de coartada para eludir la exclusiva condena de ETA, para eludir el análisis de la legitimidad de la violencia, para presentar al mal llamado nacionalismo democrático en el eje de la virtud moral y política y apoyar la orientación del voto hacia el nacionalismo, voto que en ningún caso debía ir a parar a los violentos, es decir, a todos los demás partidos. Se trataba de un análisis circunstancialmente electoralista y permanentemente partidista.

El reconocimiento, dentro del proceso de pacificación, del pluralismo de la sociedad vasca y de la reparación de las víctimas tenía por

${ }^{223}$ El Correo, 7-3-00 (21).

224 El Correo, 7-3-00 (21). 
colofón el respeto a la voluntad democrática de la ciudadanía, que por principio nacionalista no podía ser otra que la vasca. «La primera tarea de este proceso (de pacificación), continuó Lasagabaster, es, sin duda, la reparación social, moral y económica de las víctimas, pero no habrá reconciliación ni normalización desde la hegemonía y la imposición, sino desde el encuentro de voluntades y opciones democráticas» 225 . La visión de la pacificación se completaba con una denuncia del pacifismo de algunos (que no se mencionaba, pero que no podía ser otro que el pacifismo que no condenaba al Estado), que ocultaba su verdadero objetivo, el de la eliminación del nacionalismo ${ }^{226}$.

De acuerdo con estas premisas, EA se identificaba a través de Sabin Arana con el «espíritu de Lizarra», definido «como un método democrático para la resolución del problema», y con los procesos irlandés y palestino, «ejemplos de diálogo sin exclusiones, perseverancia en ese diálogo y perseverancia en la búsqueda de la paz» ${ }^{227}$. No obstante la identificación con el espíritu de Lizarra, Lasagabaster defendió un nuevo foro de diálogo, que superase tanto al de Ajuria Enea como al de Estella, en el que estuvieran «todos los que (representaban) a los ciudadanos, sin exclusión y sin agenda limitada». La posibilidad de la mediación internacional, no para «internacionalizar el conflicto, como les gustaría a algunos, sino (para) internacionalizar la solución» fue, también, mencionada por Sabin Arana ${ }^{228}$.

De momento, la estrategia de la pacificación exigía la reparación moral y material de las víctimas así como el fin de la política de dispersión para de este modo conseguir la «humanización» del conflicto ${ }^{229}$.

No hubo un segundo tema en esta sección, que destacase entre los demás. Bien por vía de resumen de la prensa, bien por boca de los propagandistas políticos se expuso el mosaico de elementos del programa a imitación o semejanza de lo que ya se ha visto en el caso del PNV, con lo que parece que se quería expresar la apuesta socialdemócrata vasca de $\mathrm{EA}^{230}$. Así constan las políticas de integración social, laboral y cultural con los inmigrantes, y, de manera especial, de acceso a los servicios sanitarios con independencia de su situación legal; la implantación de sistemas de prevención de riesgos, la investigación de las causas de la siniestralidad, especialmente en el campo de las nuevas

\footnotetext{
225 El Correo, 7-3-00 (21).

${ }^{226}$ El Correo, 7-3-00 (21), recoge toda la intervención de Begoña Lasagabaster.

227 El Correo, 10-3-00 (22). Ver Deia, 1-3-00 (5).

228 El Correo, 10-3-00 (22).

229 Ver El Correo, 6-3-00 (18), estas manifestaciones de B. Errazti.

230 Ver Deia, 29-2-00 (5).
} 
tecnologías, o la restricción de la contratación pública a empresas comprometidas con la prevención de accidentes en materia laboral; la eliminación de toda forma de discriminación y violencia contra la mujer en la vida pública y privada, reforzando los instrumentos administrativos y la asistencia jurídica, social, educativa y sanitaria; la exigencia a la Administración central de la mejora de las comunicaciones y conexiones con la cornisa cantábrica, Logroño, Navarra y Francia; la reducción de la jornada laboral a 35 horas semanales y un nuevo contrato de sustitución para trabajadores mayores de 60 años con una cotización de 35 años; la reducción de la explotación y contaminación de ríos y acuíferos además del desarrollo de la Administración Hidráulica Vasca, la elaboración de planes hidrológicos propios y la participación directa en los planes de las cuencas intercomunitarias; intensificación de la oferta pública de vivienda protegida, dirigida a los demandantes de primera vivienda, especialmente a los jóvenes (70\% de la oferta), con un 50\% en la forma de alquiler social; uso racional de los fármacos con una utilización masiva de medicamentos genéricos; la socialización de las nuevas tecnologías como elementos activos de cohesión social, el uso del euskera en aplicaciones informáticas e Internet y la instauración de una tarifa preferencial para la conexión y uso de la red para estudiantes y centros educativos; disminución de la carga impositiva de las rentas de trabajo y de las rentas más bajas, además de la continuidad en la fiscalización de las rentas de capital y las plusvalías; televisión pública con vocación de servicio orientada al impulso de los valores de tolerancia, pluralidad y solidaridad, y potenciación de los dos centros territoriales de TVE en el País Vasco con más contenidos bilingües y mayor reflejo de la configuración plurinacional del Estado; renta básica de complemento a las pensiones no contributivas a través de los impuestos generales, y pensión contributiva que supere el salario mínimo; política ambiental fundamentada en la reducción, reutilización y reciclaje de residuos y dotación de insfraestructuras adecuadas para la gestión de los mismos; la igualdad de oportunidades entre el hombre y la mujer; sistema sanitario público con seguro de cita cerrada, libre elección de especialista y de centro médico y plena competencia en las prestaciones sanitarias de Osakidetza y Osasunbidea; y, por último, la unión en alta velocidad de las tres capitales vascas y su conexión con Iruña y Zaragoza por su valor estratégico y de cohesión social ${ }^{231}$.

231 Ver El Correo, 25-2-00 (26); 26-2-00 (27); 27-2-00 (41); 28-2-00 (24); 29-2-00 (18 у 20); 1-3-00 (22); 2-3-00 (22); 3-3-00 (22); 4-3-00 (25); 5-3-00 (29); 6-3-00 (22); 7-3-00 (24); 8-3-00 (22); 9-3-00 (24 y 29); 10-3-00 (22); 11-3-00 (23). Deia y El País ofrecieron, también, durante la campaña resúmenes del programa. 


\section{Gobierno postelectoral}

No hubo, como era de esperar, alusiones explícitas al papel, que EA podía jugar en la formación del Gobierno postelectoral, salvo las obligadas (por ser un partido pequeño) palabras de Sabin Arana de que en un empate técnico entre socialistas y populares los partidos pequeños podían inclinar la balanza ${ }^{232}$. Era una forma de argumentar la petición del voto, que se sumaba a cuantos elementos definían su proyecto político. Garaikoetxea reivindicó la presencia de su partido en el Congreso para «aclarar con firmeza la legitimidad de sus reivindicaciones y desmentir la horrorosa confusión entre nacionalismo y violencia», recordando que durante la anterior legislatura la única voz nacionalista crítica en el Congreso había sido la de $\mathrm{EA}^{233}$.

Lasagabaster afirmó que EA apoyaría cualquier candidatura a la presidencia del Gobierno, que se esforzara por la pacificación y la normalización y que dejara decidir a los vascos lo que quisieran ser, bien se llamara «autodeterminación u otra cosa» ${ }^{234}$.

La defensa de los intereses vascos, la coherencia en la defensa de un mismo mensaje político en todos los foros y la afinidad con los votantes de la antigua Euskadiko Ezkerra y actual Euskal Herritarrok impulsaron a EA a pedirles el voto ${ }^{235}$.

\section{B) La crítica electoral}

\section{Euskal Herritarrok y ETA}

Este apartado, que ocupó la quinta parte de la campaña y más de un tercio de las críticas, fue en realidad un alegato contra la violencia de ETA y el seguidismo de Euskal Herritarrok ${ }^{236}$, donde ETA y su violencia casi acapararon la atención.

232 Ver El Correo, 6-3-00 (20).

233 El Correo, 2-3-00 (20).

234 Deia, 2-3-00 (10). Ver, también, El Mundo, 7-3-00 (29), donde B. Lasagabaster dice: «Siempre hemos dicho que no apoyaremos a un Gobierno que no tenga un pronunciamiento claro en dos cuestiones importantísimas. Primero, que no haga un esfuerzo clave en el tema de la pacificación. Y nuestros dos ejes en el tema de la pacificación son el respeto a los derechos humanos y el diálogo. Nos parece que no se puede apoyar a un gobierno, dejando, como si fuera un desencuentro, el gran tema clave, sería una irresponsabilidad. La segunda cuestión consiste en que ha llegado el momento en el que los ciudadanos puedan decidir qué marco jurídico-político quieren tener en el futuro».

235 Ver El Correo, 5-3-00 (26); 6-3-00 (20); 11-3-00 (22).

236 Ver Deia, 1-3-00 (5). 
De principio a fin de campaña, la razón más veces esgrimida para rechazar la violencia y pedir la disolución y desaparición de ETA fue el daño que causaba al nacionalismo y a la construcción nacional, es decir, a los propios objetivos, que ETA decía defender, bien porque directamente desprestrigiaba la causa nacionalista, bien porque provocaba una creciente reacción y un fortalecimiento de los enemigos del nacionalismo vasco. ETA, dijo su presidenta, era «el principal enemigo del nacionalismo, en cuanto (justificaba) a los inmovilistas» ${ }^{237}$. Este fue el desayuno de sus intervenciones, que terminó con la afirmación de que ETA no construía la nación, sino que la destruía ${ }^{238}$.

La persistencia de la violencia, se ha visto más arriba, además de causar sufrimiento, era la causa que destrozaba, desorientaba y desmotivaba a los nacionalistas. Los atentados de ETA conducían a la confusión entre nacionalismo vasco y violencia y estimulaban, según Garaikoetxea, «la concurrencia a las urnas de los enemigos del nacionalismo vasco en una reacción convenientemente atizada por el aparato de propaganda del Estado»239.

Errazti volvió a decir que ETA, que hacía «más daño que otra cosa a los nacionalistas», con argumentos de construcción nacional estaba «haciendo destrucción nacional» ${ }^{240}$. La presidenta del partido añadió en otra ocasión que ETA se había «convertido, de facto, en el mejor aliado político al servicio de los intereses del nacionalismo español». Su violencia, rechazable por el «sufrimiento humano que provoca», era, además rechazable, porque sus «execrables» crímenes «constituían el mejor caldo de cultivo para fomentar el odio al nacionalismo vasco» ${ }^{241}$. Atentados y excesos verbales de algunos líderes, decía Garaikoetxea, ponían en bandeja la tarea de propaganda al Partido Popular ${ }^{242}$.

El titular de Justicia del Gobierno Vasco, Sabin Intxaurraga, después de visitar a los heridos del atentado cometido en San Sebastián

237 El Correo, 28-2-00 (15). Ver, también, El Mundo, 3-3-00 (18), y Deia, 4-3-00 (10), donde se defiende que ETA es el aliado del nacionalismo español; Deia, 8-3-00 (5), donde se dice que ETA da argumentos al PP y PSOE; Gara, 28-2-00 (15), donde Lasagabaster afirma: «...No vamos a permitir que ETA nos diga lo que tenemos que hacer o por dónde van a ir los derroteros de este país. Además, desde el punto de vista político, el mayor perjuicio político es para el abertzalismo y la construcción de la práctica nacional»; Gara, 6-3-00 (12) (Sabino Arana): «No podemos dejar que ETA y el PP nos roben la esperanza por la paz».

238 Ver El Correo, 11-3-00 (22). Ver El País, 3-3-00 (5).

239 El Correo, 2-3-00 (20) y 1-3-00 (19). Ver, también, 3-3-00 (20).

240 El Correo, 2-3-00 (20).

241 El Correo, 3-3-00 (20).

242 Ver El Correo, 3-3-00 (20); El Mundo, 3-3-00 (18); Deia, 4-3-00 (10). 
por ETA, manifestó que ésta debía disolverse de una vez e insistió en que estaba consiguiendo que la gente de bien se echara contra el nacionalismo. «En su ignorancia, añadía, ETA no se da cuenta de que el mayor daño que está haciendo es contra el nacionalismo». En su opinión, los vascos ya se habían manifestado contra la pena de muerte durante el franquismo y ETA no era quien «para utilizar a su antojo la vida ajena»; más bien, debía «aplicarse lo que tanto predica: dar al pueblo la palabra y la decisión». Los atentados no ayudaban a resolver el «contencioso», ya que propiciaban el inmovilismo de quienes no querían «una solución dialogada» ${ }^{243}$.

Este atentado contra los Guardias Civiles permitió que B. Errazti recordase la postura de su partido contraria al uso de la violencia como método de construcción nacional y advirtiese a los que la utilizaban que estaban «tirando demasiado de la cuerda» y que los intereses del país podían salir vulnerados. La intervención de Garaikoetxea, con ocasión del mismo suceso, recordó que la sustitución de los cuerpos policiales del Estado por agentes vascos era uno de los objetivos de su partido, pero la pretensión de lograr tal objetivo «liquidando seres humanos (era) aberrante y un despropósito no sólo ético, sino político» 244 .

B. Lasagabaster destacó el drama humano, en primer lugar, y el fracaso político, en segundo lugar, de los asesinatos de ETA. Se refería la candidata al fracaso de ETA en mediatizar, condicionar, desvirtuar o anular la campaña con estas palabras: «Cada uno vamos a hacer lo que tenemos que hacer, porque ETA no pinta nada. Lo mejor que podemos hacer es seguir adelante como si no existiera. Ya sé que es dramático decirlo desde el punto de vista político. Si hiciéramos creer que ETA pinta algo en este país estaríamos perdidos» ${ }^{245}$.

Errazti no contestó a las críticas etarras contra EA, ya que no reconocía a ETA ninguna representación popular. «Sus últimas responsabilidades — dijo - son atentados, muerte y sufrimiento», a lo que S. Intxaurraga añadió que ETA no tenía ni «pies ni cabeza», hacía «análisis políticos irreales» y lo mejor que podía hacer era «parar y disolverse» 246 .

La atención de Eusko Alkartasuna sobre el mundo radical se centró casi exclusivamente en ETA. La poca atención que prestó a Euskal Herritarrok, lo que significaba que para EA el problema era la violencia

\footnotetext{
243 El Correo, 8-3-00 (24).

244 El Correo, 8-3-00 (24).

245 El Mundo, 7-3-00 (29).

246 El Correo, 9-3-00 (30). Ver Deia, 9-3-00 (22).
} 
de ETA no los proyectos radicales, fue para pedirle que practicara la insumisión con ETA, con el poder militar de ETA, o para rechazar su postura abstencionista o para echarle en cara su similar identidad con ETA. La crítica destacaba las consecuencias estimulantes de los enemigos del nacionalismo, la cobardía y la desidia por los intereses vas$\cos ^{247}$.

A pesar de todo lo dicho, Eusko Alkartasuna, a través de su candidato al Congreso por Vizcaya, Sabin Arana, manifestó su convencimiento de que ETA establecería un nuevo alto el fuego, «una nueva opción para la paz», que habría que gestionar sin cometer los errores cometidos en la anterior tregua ${ }^{248}$.

\section{El Partido Popular}

No llegó a tres puntos la diferencia de atención al PP en comparación con el mundo radical. Si se tiene en cuenta que ETA no era un partido político y, por ello, no era directamente un competidor electoral, aunque sí indirectamente, y que EH no se presentaba en estas elecciones, EA mostró con su fijación en los populares quién era el principal contrario político a batir. Su estrategia antipopular se basó esencialmente en la denuncia de su antinacionalismo, de su antiinstitucionalismo autonómico y de su gestión de Gobierno.

La acusación de Aznar contra el abertzalismo radical por su pretendida política de imponer por la violencia el nacionalismo étnico en Euskadi fue interpretada como un insulto con reminiscencias franquistas y una injustificable utilización electoral de la violencia por los grandes sufrimientos que ésta generaba ${ }^{249}$. Ya en la apertura de la campaña Errazti había advertido que EA no iba a tolerar que se confundiera al nacionalismo vasco con la violencia o la intolerancia, como, en su opinión, venía haciéndose desde ciertos ámbitos del poder ${ }^{250}$.

La desautorización del nacionalismo vasco a través de su identificación con la violencia era resultado objetivo, se podría decir, de los atentados de ETA, pero fruto, especialmente, de una «inmensa opera-

247 Ver El Correo, 28-2-00 (15); 2-3-00 (20); 6-3-00 (18); 9-3-00 (30). Ver, también: Gara, 43-00 (23); Gara, 8-3-00 (12); Deia, 5-3-00 (5); El Mundo, 6-3-00 (9); Gara, 7-3-00 (2); El País, 73-00 (5); Gara, 10-3-00 (18).

248 Ver El Correo, 10-3-00 (22).

249 Ver El Correo, 1-3-00 (19).

250 Ver El Correo, 25-2-00 (25). Ver Gara, 28-2-00 (15); Gara, 6-3-00 (12), donde B. Lasagabaster censura al PP por relacionar nacionalismo vasco con violencia y confundirlo con la intolerancia y la violencia; El Mundo, 7-3-00 (29). 
ción de propaganda y manipulación dirigida por el Gobierno español» en tal sentido. El Partido Popular habría puesto en funcionamiento una máquina de propaganda descomunal, desconocida desde la época de Franco, favorecida por la estrategia de ETA y los excesos verbales de algunos políticos nacionalistas ${ }^{251}$. El estímulo a la participación electoral de los enemigos del nacionalismo vasco, que causaban los atentados de ETA y la abstención de EH, era alimentado por el aparato de propaganda del Estado ${ }^{252}$. La conducta del PP en la manifestación de Buesa fue interpretada, también, en clave electoral ${ }^{253}$. Los mismos, Aznar y Oreja, que eran absolutamente contrarios al nacionalismo vasco, eran también xenófobos ${ }^{254}$.

Parece claro que lo que se quería transmitir al electorado nacionalista con estas intervenciones era que los que atacaban al nacionalismo vasco eran quienes podían recibir el rechazo de sus simpatizantes, además, por ser fascistas, franquistas o xenófobos.

Las críticas populares al Gobierno Vasco y al lehendakari, además de ser valoradas como ataque traidor y desleal con las instituciones vascas, incurrían en «actitud fascista» ${ }^{255}$. La omnipresente B. Lasagabaster habló de que, después de lo ocurrido en Vitoria (se ha de entender que después de los asesinatos de Buesa y Díaz), «vino la traición de los españoles, que han sido desleales con las instituciones vascas» ${ }^{256}$. Esta interpretación la redondeó la misma candidata al afirmar que la intervención de ETA en la campaña «se está aprovechando para atacar, no tanto a los partidos nacionalistas, sino incluso a las instituciones. El ataque contra una institución como es la Lehendakaritza ha sido proverbial. No ha sido con la forma de actuar de esa institución, sino que han ido contra la institución. Y eso es lo más grave. Y utilizaron la manifestación» 257 .

El resto de la crítica a la política del PP incluyó: la decisión por la que el cuadro Guernica de Picasso seguía en Madrid, que iba acompañada de la petición de su traslado a Euskadi fundada en pintorescas justificaciones como la de ser un «símbolo de las deudas contraídas por Madrid con Euskal Herria» o significar «paz y guerra, pero también deudas por inmovilismo, por falta de profundización democrática o de

\footnotetext{
251 Ver El Correo, 3-3-00 (20).

252 Ver El Correo, 3-3-00 (20).

253 Ver El Correo, 28-2-00 (15).

254 Ver El Correo, 6-3-00 (18).

255 El Correo, 3-3-00 (20).

256 Gara, 6-3-00 (12).

257 El Mundo, 7-3-00 (29).
} 
articulación democrática» ${ }^{258}$; la mala actuación del Gobierno español en la Unión Europea ${ }^{259}$; la detención de Olarra, sobre la que manifestó Gorka Knorr que resultaba «sorprendente que quien se dedica a quitar el polvo a los expedientes judiciales lo haga en medio de la campaña, y no antes o después» ${ }^{260}$; la descoordinación en el tema portuario, especialmente en lo relativo al Puerto de Bilbao, con la correspondiente reclamación de las transferencias de los puertos de Bilbao y Pasajes ${ }^{261}$; el tratamiento de la tregua de ETA y del proceso de paz, que se calificó de provocación y de la «peor gestión en los últimos cuatro años» ${ }^{262}$; y el entendimiento entre Mayor Oreja y Chevenement, de quien Garaikoetxea lamentó su oposición a un Departamento Vasco en Francia para no debilitar la unidad de España, interpretada como xenofobia ${ }^{263}$.

La pésima valoración del PP fue tal que se le vio pactando con el Partido Nacionalista Vasco después de las elecciones, no obstante las «trifulcas» entre ambos partidos. «La polarización — dijo Garaikoetxea- se nos hace justificadamente sospechosa porque algo parecido ha pasado en todas las campañas y luego se han producido los pactos que conocemos» ${ }^{264}$.

Al mismo político la campaña le había parecido la más impúdica de cuantas se habían celebrado durante la democracia. El Partido Popular, juntamente con el PSOE, habría roto todas las reglas del juego ${ }^{265}$.

\section{Partido Nacionalista Vasco}

Aunque el PNV no fue la preocupación fundamental de EA (no llegó al 10\% del total de la campaña), sí atrajo su atención bastante más de lo que ocurrió en el caso contrario. Se ha visto cómo el Partido Popular fue la obsesión crítica de los nacionalistas del PNV después de varios años de pactos y entendimientos en la anterior legislatura. Pues bien, la denuncia de estas relaciones entre populares y peneuvistas fue la esencia de la crítica de EA.

258 El Correo, 29-2-00 (18). Ver El País, 29-2-00 (3); Gara, 29-2-00 (18); Deia, 29-2-00 (5).

259 Ver El Correo, 3-3-00 (20).

260 El Correo, 3-3-00 (26). Ver El Mundo, 3-3-00 (17).

261 Ver El Correo, 5-3-00 (26).

262 El Correo, 10-3-00 (22); ver, también, 6-3-00 (20) y 1-3-00 (19), sobre la vía policial; Gara, 4-3-00 (23); El País, 29-2-00 (24); Gara, 6-3-00 (12), donde se habla de que tanto ETA como el PP intentan robar la esperanza por la paz.

263 Ver El Correo, 11-3-00 (22).

264 El Correo, 8-3-00 (20).

265 Ver El Correo, 8-3-00 (20). Ver, también, El Correo, 1-3-00 (19), y Deia, 8-3-00 (5). 
Lo planteó con toda claridad al comienzo de la campaña B. Errazti, cuando se refirió a las «mudanzas continuas en su actitud» (PNV) con respecto a los populares. «No se puede decir - añadió- que Aznar es el mejor del mundo mundial (sic) y después de una riña de enamorados poco tiempo antes de terminar la legislatura romper con él» ${ }^{266}$. Un compromiso de difícil cumplimiento, que silenciaba pactos presentes, siguió a tales críticas. EA no podría «pactar con aquellos que tienen tantos cambios» ${ }^{267}$.

Durante la legislatura anterior, en opinión del expresidente de EA, fue la diputada Begoña Lasagabaster «la única voz de la oposición nacionalista» en desarrollar un trabajo crítico con el Gobierno, mientras que populares y peneuvistas mantuvieron sus pactos ${ }^{268}$.

La convicción transmitida al electorado era la de que, a pesar de la ruptura de sus relaciones, el PNV volvería a pactar con un Gobierno popular, si Aznar ganara las elecciones. Así lo manifestó Mikel Mintegi, quien veía normal que los populares (además de los socialistas) no pidiesen que no se votara a Anasagasti, ya que el candidato nacionalista «votó a favor de la investidura de Aznar, a tres presupuestos del PP y al $90 \%$ de las iniciativas del Congreso» ${ }^{269}$. «En menos de seis meses el PNV estará apoyando de nuevo al PP», dijo B. Errasti ${ }^{270}$. Por eso se ha visto que a Garaikoetxea le parecía «justificadamente sospechosa» la polarización de la campaña entre populares y nacionalistas del PNV.

Al final de la campaña se siguió la misma línea argumental, aunque complementada con la necesidad de responder a Anasagasti, que había afirmado que dar a EA 40.000 votos en Vizcaya era tirarlos a la basura. La presidenta del partido habló de que el voto al PNV era un voto a Mayor Oreja y a Aznar, y el expresidente recordó que el PNV, después de haber estado gobernando con el PSOE durante 14 años en perfecta sintonía, había estado «otros cuatro años con la caverna de la derecha», por lo que «la basura ha podido estar allí, pero no en las urnas donde recoge el voto $\mathrm{EA} »^{271}$.

Sabin Arana interpretó la presencia durante años de Anasagasti en Madrid como un intento de hacer «méritos para ser ministro en Ma-

266 El Correo, 28-2-00 (15). Ver El Mundo, 28-2-00 (8).

267 El Mundo, 28-2-00 (8).

268 Ver 2-3-00 (20).

269 El Correo, 4-3-00 (24). Ver El Mundo, 7-3-00 (4), donde B. Lasagabaster manifiesta: «No me sorprendería nada que el PNV volviera a pactar con el PP en Madrid»; $E l$ Mundo, 5-3-00 (11); El País, 29-2-00 (24): del idilio a la acusación.

270 Gara, 7-3-00 (1). Ver Gara, 7-3-00 (20).

271 El Correo, 11-3-00 (22). Ver Gara, 11-3-00 (18); El Mundo, 11-3-00 (10). 
drid». El mismo político le recordó a Arzalluz su criterio anterior de que la dispersión de los presos no era «una vulneración de los derechos humanos» 272 .

\section{Partido Socialista}

El PSOE apenas entró en los cálculos de Eusko Alkartasuna de manera independiente.

Resultaba lógico que así fuese, ya que para EA la campaña en el País Vasco se había polarizado entre el PP y el PNV. Algunas de las acusaciones, no obstante, las compartió con el Partido Popular por aquello de formar un supuesto bloque españolista contra el nacionalismo vasco (campaña impúdica, enemigo del nacionalismo vasco). Incluso compartió la reprimenda tras la manifestación por Buesa, aunque en ese caso se llevó la mayor parte de la agresividad por su supuesta actitud fascista, irresponsable, electoralista y creadora de riesgo para la convivencia civil ${ }^{273}$. Pero en realidad, los socialistas, vigente aún la validez de los principios del Pacto de Lizarra, se merecían por parte de EA la misma consideración que los populares en tanto en cuanto ambos eran ajenos al mundo nacionalista e integraban a las fuerzas españolas, consideración que se expresó en las siguientes palabras de la presidenta del partido: «Están preocupadas (las fuerzas españolas) por oírnos hablar de paz, porque como están más cómodos así, tienen que intentar eliminar cualquier tipo de esperanza, ya que saben que cuando desaparezca la violencia, nosotros nos dedicaremos a hacer nuestro país» ${ }^{274}$.

Según esto, los socialistas se sumarían al PP y a ETA en cuanto ladrones de la esperanza ${ }^{275}$, a pesar de que B. Lasagabaster opinase que últimamente se había producido un distanciamiento del PSOE con respecto al Partido Popular, que podría dar lugar a algún cambio, cosa que gustaría al partido de $\mathrm{EA}^{276}$.

\footnotetext{
272 Gara, 11-3-00 (18).

273 Ver El Correo, 28-2-00 (15); El Mundo, 28-2-00 (8).

274 El Correo, 11-3-00 (22).

275 Ver Gara, 6-3-00 (12).

276 Ver El Mundo, 7-3-00 (29).
} 